\title{
A Century of Riverbank Protection and River Training in Bangladesh
}

\author{
Knut Oberhagemann $^{1, *}$, A. M. Aminul Haque ${ }^{2}$ and Angela Thompson ${ }^{1}$ \\ 1 Northwest Hydraulic Consultants, Edmonton, AB T6X 0E3, Canada; athompson@nhcweb.com \\ 2 Bangladesh Water Development Board, Dhaka 1205, Bangladesh; ashama62@gmail.com \\ * Correspondence: koberhagemann@nhcweb.com
}

Received: 27 September 2020; Accepted: 25 October 2020; Published: 27 October 2020

\begin{abstract}
Protecting against riverbank erosion along the world's largest rivers is challenging. The Bangladesh Delta, bisected by the Brahmaputra River (also called the Jamuna River), is rife with complexity. Here, an emerging middle-income country with the world's highest population density coexists with the world's most unpredictable and largest braided, sand-bed river. Bangladesh has struggled over decades to protect against the onslaught of a continuously widening river corridor. Many of the principles implemented successfully in other parts of the world failed in Bangladesh. To this end, Bangladesh embarked on intensive knowledge-based developments and piloted new technologies. After two decades, successful, sustainable, low-cost riverbank protection technology was developed, suitable for the challenging river conditions. It was necessary to accept that no construction is permanent in this morphologically dynamic environment. What was initially born out of fund shortages became a cost-effective, systematic and adaptive approach to riverbank protection using improved knowledge, new materials, and new techniques, in the form of geobag revetments. This article provides an overview of the challenges faced when attempting to stabilize the riverbanks of the mighty rivers of Bangladesh. An overview of the construction of the major bridge crossings as well as riverbank protection schemes is detailed. Finally, a summary of lessons learned concludes the impressive progress made.
\end{abstract}

Keywords: Brahmaputra; Bangladesh; riverbank protection; river training; geobag revetments; adaptive approach

\section{Introduction}

\subsection{The Disaster Prone Ganges and Brahmaputra Delta}

"He had heard it said, by one who knew them well, that the longer one studied the Bengal rivers the less one understood them; dread of their vagaries certainly increased with closer acquaintance." Mr. J.N.D. La Touche in correspondence with Sir Robert Richard Gales on the Hardinge Bridge over the Lower Ganges at Sara, reported by Gales in 1917 [1].

The development of river training works and riverbank protection in Bangladesh is closely linked to how the fast-growing and developing population attempts to deal with one of the most hazard-prone deltaic landscapes on earth. The Ganges and Brahmaputra (named the Jamuna in Bangladesh) are among the ten largest rivers of the world [2]. Both rivers join in Bangladesh to form the Padma River (Figure 1). The Padma River has a discharge of approximately $150,000 \mathrm{~m}^{3} / \mathrm{s}$ during a 100 year flood event [3] and an estimated annual average sediment load between 0.5 and 1 billion tons [4]. With an annual average discharge of $30,000 \mathrm{~m}^{3} / \mathrm{s}$, the Padma is the third largest river in the world (in terms of discharge), only surpassed by the Congo and Amazon. 
These immense rivers flow through intensively used land; Bangladesh leads the world in population density of area states with more than 1100 persons $/ \mathrm{km}^{2}$. In comparison, the population density of both The Netherlands, the most populated country in Europe, and India is just over 400 persons $/ \mathrm{km}^{2}$. That of the US is less than 40 persons $/ \mathrm{km}^{2}$. Over $90 \%$ of the catchment areas of both rivers lie outside of Bangladesh.

Floods, cyclones, and erosion (river and coastal) contribute to nearly $60 \%$ of all disaster damages in Bangladesh, costing USD 2.5 billion between 2009 and 2014 [5]. Nearly threequarters of these water-related losses were associated with floods, with the two largest components related to crops $(36 \%)$ and houses (17\%). Another one-quarter of these water-related losses were attributed to erosion. Despite these challenges, Bangladesh is currently moving from the status of among the least developed countries to a middle-income country. Economic interests, food security, and the increasing assets of a fast-growing population are the main drivers for infrastructure developments that address the natural hazards of the low-lying, flat deltaic landscape (Figure 2).

The Jamuna River is the single most significant cause of natural hazards. This is largely because the Jamuna River has been widening. This widening is a consequence of the Great Assam Earthquake in 1950, which dislodged some 45 billion cubic meters of sediment from the eastern Himalayan mountain slopes [6,7]. In Bangladesh, this sediment overloading triggered an increase in the average width of the Jamuna from 8 to $12 \mathrm{~km}$, while the Padma River widened from 6.5 to nearly $11 \mathrm{~km}$ from the $1970 \mathrm{~s}$ to the 2010s. During this period, the Jamuna turned into a braided river; however, it still had some meandering and anabranched reaches as recently as the mid-1980s (Figure 3). The braided characteristic is strongly associated with ever-changing channel patterns, which result in several thousand hectares of annual erosion. Local erosion eats laterally into the floodplain by as much as $1 \mathrm{~km}$ in one season. The extent and location of riverbank erosion along the Jamuna can be reasonably predicted only one year in advance [8]. The Padma River, despite being more powerful, is more predictable. This is because some of its banks consist of more erosion-resistant clay, making its planform swing between anabranched and meandering at a slower, more predictable pace. Since the mid-1990s, the annual average erosion rates along the Jamuna and Padma Rivers have halved from approximately 6300 ha (from 1973 to 1997) to approximately 3300 ha (thereafter until 2019) (Figure 3). The Ganges River, being a meandering river, is also more predictable. Downstream, the Lower Meghna debouches the combined flow of the Ganges, Jamuna, and Upper Meghna into the Bay of Bengal. The Lower Meghna (as well as the Upper Meghna during the dry season) is tidal and its length is almost entirely part of the estuary.

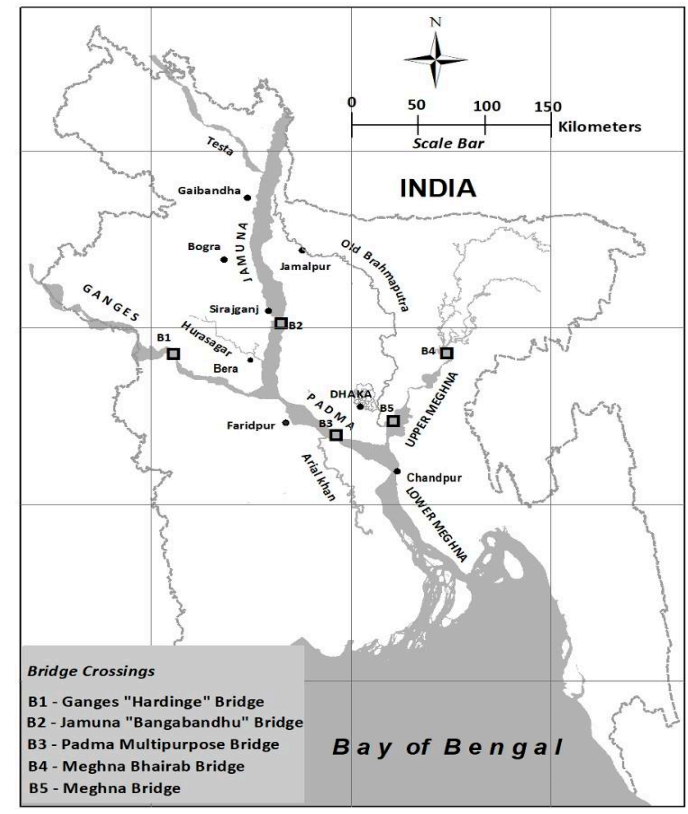

Figure 1. Bangladesh with main rivers and locations relevant to this article. 


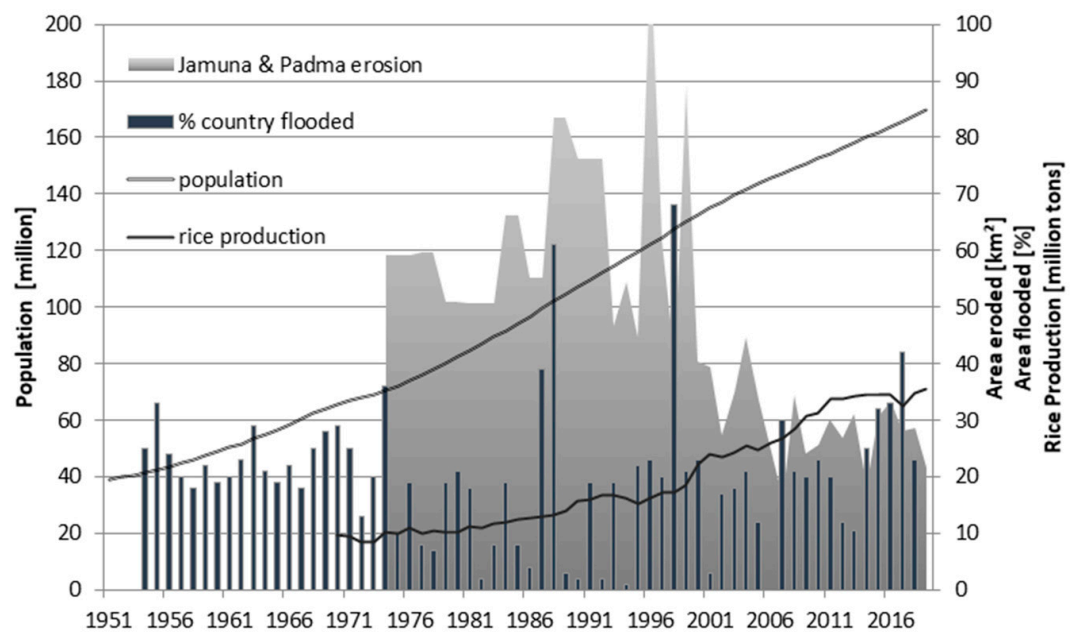

Figure 2. The natural environment of Bangladesh expressed in area flooded (in percentage of Bangladesh) and eroded land along the Jamuna and Padma Rivers (in $\mathrm{km}^{2}$ ) compared with the population growth and annual rice production (in million metric tons) (data source: CEGIS).
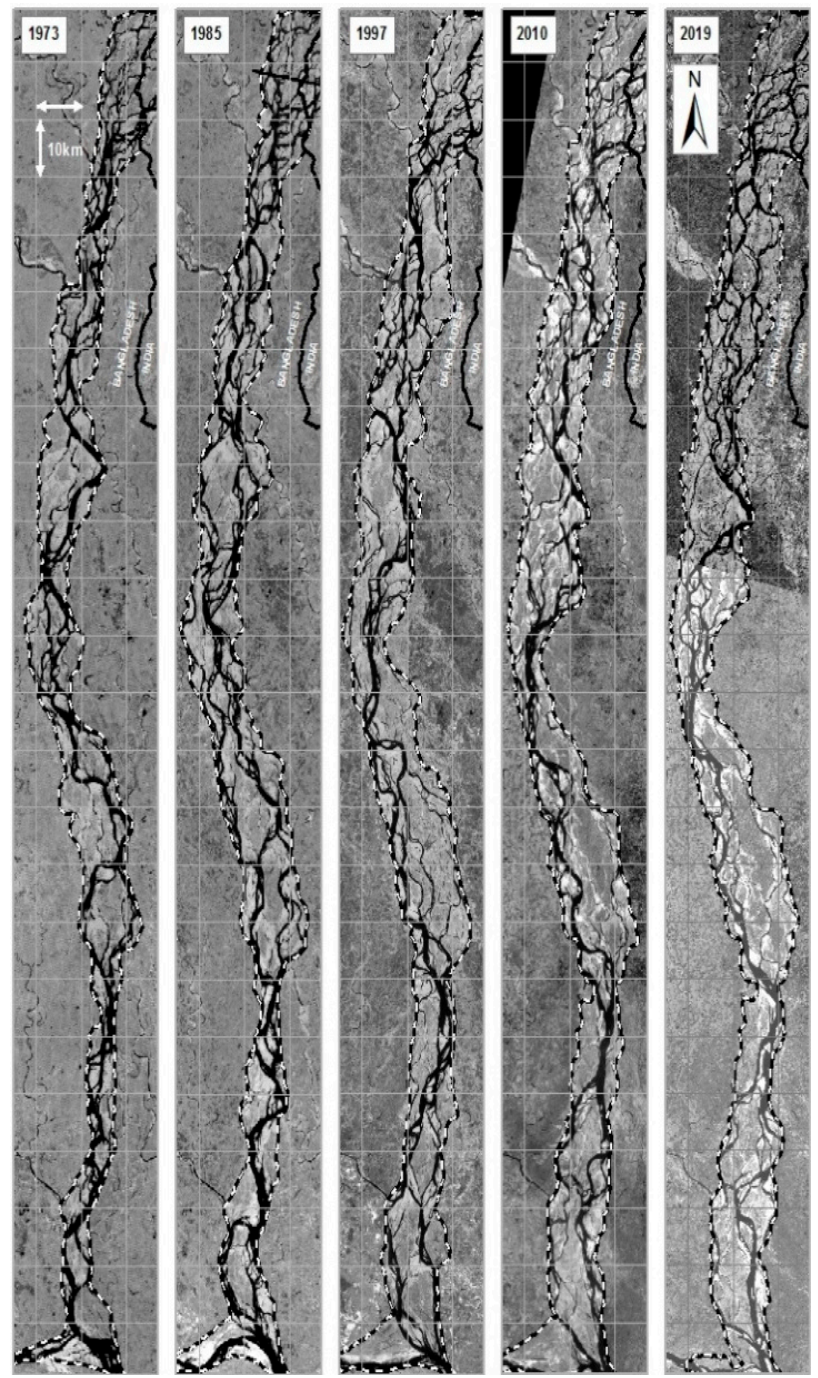

Figure 3. Dry season imagery of the Jamuna River over nearly half a decade (dashed lines show the flood plain boundaries) (source: CEGIS). 


\subsection{Challenges of Training Rivers and Protecting Riverbanks in the Bangladesh Delta}

It is a combination of factors that makes the construction of cost-effective and sustainable works alongside these very large rivers extremely challenging. The factors relate not only to design issues associated with the soil, the water, and the structure [9], but also to much larger issues such as the country's geostrategic location, policies, the institutional framework, ecological considerations, and financing. The main challenges are elaborated upon below.

\section{Hydrogeology:}

(i). Bangladesh occupies the lower $8 \%$ of the Ganges Brahmaputra basin, which is dominantly shared by two powerful countries, India and China. The country has little influence on upstream basin and water resource developments and is strongly affected by sea level rise.

(ii). The annual monsoon dominantly influences the water resources of Bangladesh. River discharges can change by 20-fold or more and water levels can rise by up to seven meters from dry season to monsoon season flows. Most of the flooding is caused by the monsoon rains from outside of Bangladesh, which are transported by the large rivers through the country into the Bay of Bengal.

(iii). Bangladesh is affected by earthquakes. The eastern Himalayas have experienced some of the largest earthquakes in the world. While the alluvial soils dampen earthquake impacts to some extent, they are also prone to liquefaction. No major earthquake has hit Bangladesh in the last 70 years and all its major infrastructure, built over the last half century, has never experienced this unique loading case.

\section{Planning:}

(i). Bangladesh is deprived of rock. It only operates one granite mine which extracts limited amounts of rock from several hundred meters below ground. The size of this rock is too small for riprap exposed to high flow velocities.

(ii). The future channel pattern is of low predictability. There is a predictability of one to two years for the major rivers. Consequently, planning requires flexibility when determining the location of riverbank protection works, as erosion sites can suddenly shift.

(iii). Long processing periods conflict with quick river changes. It typically takes several years between identifying an erosion prone location until the completion of the construction. During this time, the location of the works is fixed, while the river continuously changes.

(iv). Budgetary provisions are focused on new construction and not on monitoring, evaluation, adaptation and maintenance. The Bangladesh Water Development Board (BWDB) allocates only approximately $10 \%$ of the funds required for identified operation and maintenance requirements. Its annual budget is only slightly larger than the total estimated annual requirement for operation and maintenance [10].

\section{Design and Implementation:}

(i). The soils are mostly comprised of fine, easily erodible and variable alluvial deposits, consisting primarily of poorly graded sands and silts with locally varying percentages of mica. The topsoils are subject to liquefaction during earthquakes and slopes are subject to flow slides during fast scouring (or unloading at the toe). Subsoil investigations often do not provide a full picture of the variability of the soil due to a limited number of boreholes.

(ii). Flowing water erodes the fine bed and bank material, even at low velocities. High velocities during floods create extremely deep scouring (up to $30 \mathrm{~m}$ vertical during one season). Waves are typically limited to approximately $1 \mathrm{~m}$ height.

(iii). The structure, or riverbank protection works, is intended to separate the water from the soil and thereby preventing soil erosion. The challenge is to design cover layers that are flexible enough to adjust to changes of the underlying soil and at the same time being heavy enough to 
resist high flow or wave loading. This often requires careful balancing of opposing requirements, for example, heavy protective layers are favorable in withstanding high-flow forces but could destabilize slopes particularly on weaker soils.

(iv). The performance of toe aprons determines the stability of riverbank protection and river training works. Aprons are necessary as dredgers cannot dredge to the deepest scour levels. Given the variable nature of flow and soil conditions, aprons add an element of uncertainty given that they are expected to provide self-launching protection over geotechnically stable slopes, separating the fast and highly turbulent flow from the easily erodible sands and silts of the riverbanks.

(v). The construction window is limited to times of low water levels and flow velocities (during the dry season from December to May). Even during this period, the rivers remain morphologically active, so construction must remain flexible.

\section{Monitoring and Evaluation:}

(i). Monitoring in the deep and fast-flowing rivers remains challenging. General surveys concentrate on water levels and bathymetries, while flow and sediment discharge data are not collected systematically. Some of the constructed works have been surveyed regularly (bathymetric surveys). The data on riverbank protection and river training works are sufficient to provide good indications on scour depth and underwater slopes, but insufficient for creating systematic risk-based designs. Systematic scuba-diving investigations have been conducted for some projects and contributed much to the understanding of the portion of the structures which are underwater (which is the majority of the structure).

\subsection{This Article}

This article summarizes the authors' experience with riverbank protection and river training works gained over the last two and a half decades in Bangladesh. This article also provides lessons learned. The authors contributed to the analysis of existing work in 2000 [11], the development of sand-filled geotextile bag (geobag) revetments from 2001 until 2008 [12,13], the design of the river training works for Padma Bridge from 2009 until 2011 [3], the implementation of the Flood and Riverbank Erosion Risk Management Program from 2015 until 2020 [14,15], and the preparation of a "river stabilization plan" [16]. Experience with river training is summarized in Chapter 2. Chapter 3 focusses on riverbank protection, concentrating on the most relevant experience over the last 25 years. Finally, Chapter 4 summarizes key experiences and lessons learned.

\section{Developments in River Training (Since the 1910s)}

"The Bell bund method not only reduced the first cost of the bridge proper, but, what was of more importance, it reduced the cost of maintenance of the training works, which was such a formidable item with the spur system. In short, it made possible the construction of permanent and workmanlike bridges in situations where this had not previously been found possible. All honor to James Richard Bell!" Sir Robert Richard Gales in the Principles of River-Training for Railway Bridges, 1938 [17].

The first large infrastructure projects in Bangladesh date from the British colonial period. The development of a comprehensive railway network in British India from the mid-19th century onwards resulted in the development of a large number of river crossings (as well as changes in the flood and drainage patterns through the high and long lateral embankments constructed for railway lines). Bridge crossings were based on two principles published in the late 19th century $[17,18]$. First, abutments were stabilized with "Bell bunds", later named "guide banks" or "guide bunds". The second principle relates to the placement of "armor stone" along the riverbed, termed the "apron". All bridge crossings in Bangladesh depend on aprons, while many have guide bunds. 
Major river training work for bridge engineering is limited to three locations on the Ganges, Jamuna and Padma Rivers in Bangladesh (Figure 4). (There are two more bridge crossings over main rivers, namely the Upper Meghna, at Bhairab, consisting of a railway bridge completed in 1937 and a road bridge completed in 2002; and two road bridges near Dhaka most popularly known as the Meghna Bridge and the second Meghna Bridge, completed in 1991 and 2019. However, these bridges are of less significance in river engineering terms due to the comparatively stable river characteristics.) The Hardinge Bridge crosses the Lower Ganges at Sara. It was constructed between 1909 and 1914 [1,17], with a road bridge added downstream during the first years of the 21st century. The Jamuna Multipurpose or Bangabandhu Bridge crosses the Jamuna downstream of Sirajganj. It was constructed between 1996 and 1998 [19], with an upstream railway bridge now being planned some 20 years after the bridge inauguration. The Padma Multipurpose Bridge crosses the Padma River near Mawa [3]. Its construction started in 2014, with the bridge expected to be opened in the early 2020s.

The following quotes from engineers involved with the large bridge crossings provide insight into the challenges faced:

Spring reported about the Ganges crossing [1]:

"The conclusion to which I have come is that the task of bridging the Lower Ganges is an exceptionally formidable one. Of this class of work nothing approaching it in difficulty has been attempted in India, or, indeed, so far as I know, anywhere else. The difficulty to which I refer is not in the building of the bridge, which is the usual straight-ahead bridge work, but in the training of the river so that it may not desert the bridge when built."

Tappin et al. [19] on the Jamuna crossing:

"Bridging the Jamuna presented considerable economic and technical challenges to the consultants and contractors alike. Issues of particular complexity where the training of the braided river and the design and construction of the bridge foundations in an alluvial flood plain where the rock formation lies several $\mathrm{km}$ below the river bed. The scale of the undertaking, both with regard to river training and to foundations, is without precedent and makes the achievement of particular engineering interest."

Neill et al. [20] about the Padma crossing:

"The design of river training works for the Padma Bridge poses severe problems in river engineering, similar in nature but probably greater in severity than have been faced in other large bridge projects in Bangladesh. These problems include the very large scale and the periodic shifting of the river, the extremely fine non-cohesive boundary materials, the great potential depths of scour, potential geotechnical instability, and the high cost of traditional erosion protection materials such as rock riprap that have to be imported from abroad."

The river training associated with each of the three bridges is unique. Table 1 summarizes key parameters for each bridge based on available information from key references. Key information includes the equivalent 2019 construction cost, despite the challenges escalating the cost of the century old Ganges crossing. In terms of cost, the Jamuna crossing is the only river training works that was more expensive than the bridge cost. The river training works amounted to half of the overall total cost, whereas it amounted to approximately one-third of the total cost for the other two bridges. Overall, the total length of protection has reduced from three times the bridge length for the Ganges to less than two times for the Padma crossing. 

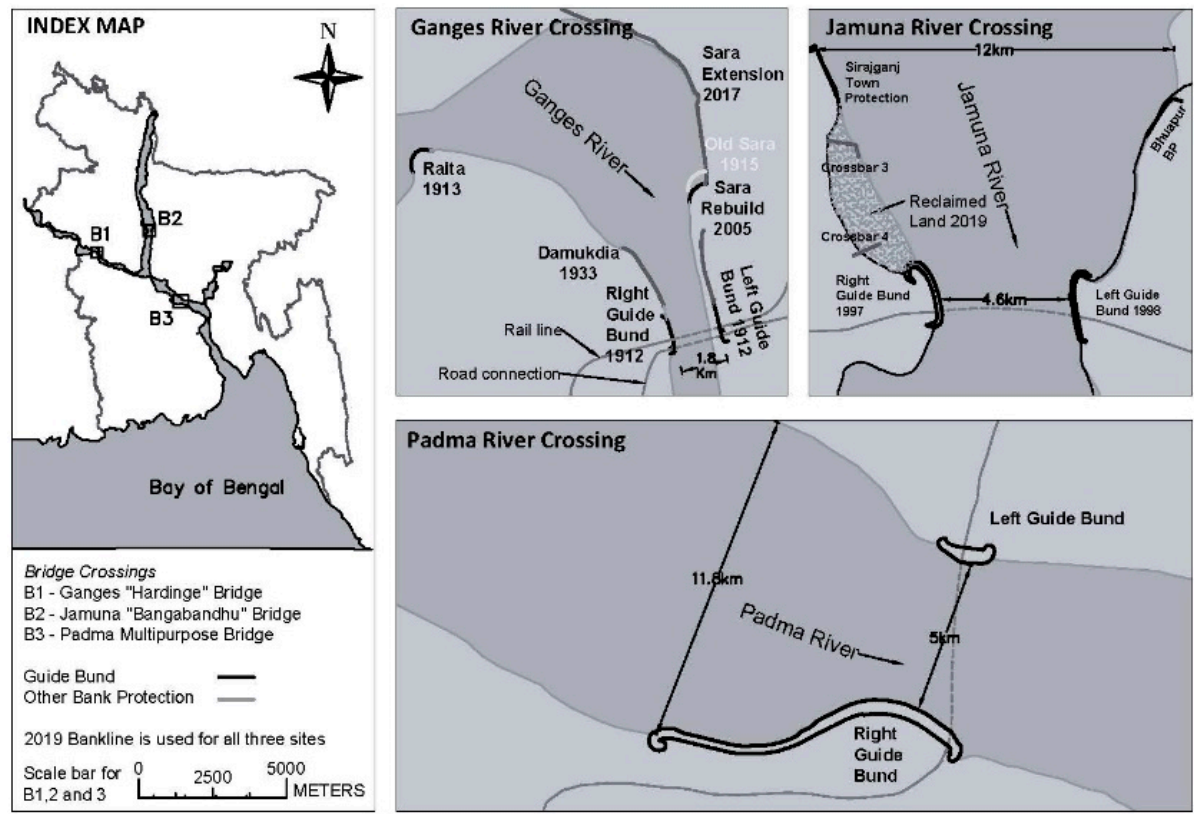

Figure 4. Comparison of guide bunds for the three major bridge crossings in Bangladesh.

Table 1. Comparison of river training works in Bangladesh (RTW = river training works).

\begin{tabular}{|c|c|c|c|}
\hline River & Ganges & Jamuna & Padma \\
\hline Bridge length & Hardinge: $1578 \mathrm{~m}$ & $4800 \mathrm{~m}$ & $6150 \mathrm{~m}$ \\
\hline Bridge type & $\begin{array}{l}\text { Hardinge: Rail } \\
\text { Lalon Shah: Road }\end{array}$ & Road and rail & Road and rail \\
\hline Start of planning & 1887 & 1972 & 1987 \\
\hline Construction period & $\begin{array}{l}\text { Hardinge: 1910-1915 } \\
\text { Lalon Shah: 2000-2005 }\end{array}$ & $\begin{array}{l}\text { 1994-1998 } \\
\text { (Railway bridge construction } \\
\text { has started in 2020) }\end{array}$ & 2014-2022 (estimate) \\
\hline RTW: Guide bunds & $\begin{array}{c}1000 \text { m (left bank) } \\
1000 \text { m (right bank) }\end{array}$ & $\begin{array}{c}3070 \text { m (left bank) } \\
3260 \text { m (right bank) }\end{array}$ & $\begin{array}{c}1400 \text { m (left bank) } \\
10,800 \text { m (right bank) }\end{array}$ \\
\hline $\begin{array}{c}\text { RTW length/Bridge } \\
\text { length }\end{array}$ & $302 \%$ & $216 \%$ & $197 \%$ \\
\hline $\begin{array}{l}\text { Original cost of } \\
\text { Bridge/RTW/Total in } \\
\text { original currency }\end{array}$ & $\begin{array}{c}1.2 / 0.6 / 2.3 \\
1917 \text { GBP (million) }\end{array}$ & $\begin{array}{c}435 / 530 / 1,260 \\
2000 \text { USD (million) }\end{array}$ & $\begin{array}{c}\text { 1450/1120/2890 } \\
2019 \text { BDT (billion) }\end{array}$ \\
\hline $\begin{array}{l}\text { Equivalent } 2019 \text { cost } \\
\text { of Bridge/RTW/Total } \\
\text { (in USD million) }\end{array}$ & $197 / 100 / 373$ & $443 / 653 / 1380$ & $1445 / 1120 / 2890$ \\
\hline $\begin{array}{l}\text { RTW to bridge cost } \\
\text { ratio }(\%)\end{array}$ & $51 \%$ & $150 \%$ & $77 \%$ \\
\hline
\end{tabular}

Each bridge crossing was technologically cutting edge and daring. They all contributed to the understanding of river training works for large alluvial rivers. Noteworthy aspects include: 
(i). Purpose of river training: While the Ganges River training works focused on fixing a meandering river, the two other crossings narrow the multichanneled rivers from approximately $12 \mathrm{~km}$ upstream to $5 \mathrm{~km}$ under the bridge.

The Jamuna crossing changed the braided river substantially downstream. After adjustment to the guide bunds, the Jamuna River flowed in a single $4 \mathrm{~km}$ wide straight channel downstream. This straight channel provided stability over a $15 \mathrm{~km}$ long reach; however, the subsequent downstream channel bifurcation increased the bank erosion in the Lower Jamuna [26]. In 2012, the straight channel was destabilized through the capital pilot dredging project attempting to form a short cut of the outflanking channel between Sirajganj and the west guide bund [16]. While this pilot project resulted in some $11 \mathrm{~km}^{2}$ of land reclamation between Sirajganj and the west guide bund, it led to erosion on the left bank downstream of the bridge.

The river training works of the Padma crossing follows the outer enveloping curve of historic riverbanks and is therefore not expected to interfere with the natural channel development.

(ii). Guide bunds with upstream protection versus continuous work: The Ganges crossing applied the guide bund principle to the largest river crossing built during British colonial times and has been successful for over a century. For the Ganges crossing, the importance of upstream work on both riverbanks to reduce the shifting of the meandering river was recognized. The same principle was applied for the Jamuna crossing and has been successful for one-quarter of a century. At the Jamuna crossing, both the shape and length of the guide bunds was changed from the British standards towards shorter, differently curved, and oriented works [27].

For the Padma Bridge, the guide bund principle with upstream hard points was abandoned in lieu of continuous protection to avoid problems with outflanking flows [3]. However, this was only necessary on one bank, as the other bank consisted of erosion-resistant material requiring little additional work in the area of the bridge. The major motivation for providing long, guiding revetments along the existing, more consolidated riverbanks instead of moving a shorter guide bund into the river as for the west guide bund of the Jamuna crossing, was to reduce the potential for geotechnical failures.

(iii). Underwater works: Similar to the developments of the layout of guide bunds and upstream supporting works are the developments of the underwater protection. While the Ganges crossing depends on aprons placed in the dry above low water level and continuously maintained through additional dumping, the other two bridges depend on deep computer-aided dredging with cutter suction dredgers to approximately $25 \mathrm{~m}$ below low water level (for example [28]). Dredging provides the advantage of allowing a deep placement of the apron closer to the design scour depth. This reduces the uncertainties, as much of the underwater slope can be fully protected on a geotechnically stable slope. This deep apron has proven successful as scouring only surpassed the apron level at each guide bund of the Jamuna crossing once in 20 years [29]. However, at the northern bank at the Padma Bridge, the bed levels were below the dredged apron level immediately prior to construction (2011-2014), showing how the ability to launch is still a critical feature of the aprons.

(iv). Crossing location: Dredging and placing the underwater protection under still-water conditions dictated the location of the Jamuna crossing [30]. The area for the right guide bund in the river perpetually shifted with the location of a suitable char (river island). The right guide bund as well as the bridge location could only be fixed one year after the construction contract had been signed during the dry season (1995/1996).

In case of the Padma Bridge, the location of the crossing was fixed as the land acquisition for the road alignment was already underway. The closeness of the southern approach road as well as of several resettlement villages to the river was a secondary reason for abandoning the guide bund and hard point concept, as erosion in between them would have threatened both the road and the settlements. 
(v). Protective elements: Apart from setting the apron at deeper levels, the protective elements were also changed. While the Ganges crossing depended solely on "one man armor stones" (30 to $75 \mathrm{~kg}$ ), which were carried individually by workers, the Jamuna Bridge used 10-100 kg riprap for the slope protection while a widely graded riprap was placed as falling apron (1-115 kg). The underwater slope was first covered with "fascines", a two layer geotextile filter cloth attached to bamboo frames of up to $30 \times 155 \mathrm{~m}\left(4650 \mathrm{~m}^{2}\right)$ in size and sunken through boulder ballast, before the riprap was placed.

At Padma Bridge, given the risk of working in flowing water, fascines were replaced by three layers of $125 \mathrm{~kg}$ geobags, which can be placed quickly and are stable to flow velocities of up to $3 \mathrm{~m} / \mathrm{s}$ [31]. This bag-filter layer is covered with graded riprap weighing between 40 and $1000 \mathrm{~kg}$ in the more exposed curvature on the right bank and both bridge area. The upstream areas are protected with multiple layers of geobags alone. The toe protection included additional risk mitigation measures: the apron is up to $65 \mathrm{~m}$ wide to reduce the risk of failure from flow slides during rapid scouring and follows an adaptive approach with upgrading of the apron immediately after launching. All aprons consist of geobags because of their wide, flat dimensions and flexibility which reduces the void ratio and prevents winnowing. When dumped close to the surface by using dumping guides, high precision in layer thickness and coverage can be achieved.

(vi). Learning by doing: Much was learned from failures, particularly at the Ganges crossing. After some smaller failures during previous years, the upstream part of the right guide bund failed on 26th September 1933, followed by a second major slip on 25 October 1934 [17]. At this time, the flow was approaching the guide bund under a strong angle and it is highly likely that the apron failed through winnowing. The failure of the guide bund resulted in major physical hydraulic model investigations to assist repair works. As part of these investigations Inglis studied the performance of aprons consisting of angular and rounded rock and indicated the launching on 1V:2H slopes in single layer, first discussed in the paper of Gales, 1938 [16] and finally published in 1949 [32].

At the Jamuna crossing, a number of flow slides developed during construction along the dredged slope of the western guide bund [19]. As a result of these slides the underwater slope was changed from $1 \mathrm{~V}: 3.5 \mathrm{H}$ to $1 \mathrm{~V}: 5 \mathrm{H}$ or $1 \mathrm{~V}: 6 \mathrm{H}$. In 2006 the Jamuna crossing western guide bund developed a deep (more than $45 \mathrm{~m}$ below average flood level and some $18 \mathrm{~m}$ below apron setting level) but only $200 \mathrm{~m}$ long scour hole along the falling apron at the upper curve [29]. The scour hole was associated with outflanking flows from upstream and was deeper than the design scour. In 2007, the lower slope protection in this area failed. One explanation is that rapid repeated scouring at the toe triggered slides of loose deposits down the protected slope and flow slides under the fascine mattress due to sudden unloading.

(vii). Adaptation and maintenance: The guide bunds at the Ganges crossing appeared to be supplied regularly with rock directly from the railway tracks that run parallel to the guide bunds (see [17]). The deeper apron setting level at the Jamuna crossing has reduced the required maintenance works and only one failure has been reported.

\section{Developments in Riverbank Protection (Since the mid-1700s)}

"A spur may be defined as any solid projection from the river bank into running water, which is the cause of stationary, eddies. The spur form, intentional or unintentional, is the cause of most of the difficulties which afflict river-training." Sir Robert Richard Gales in the Principles of River-Training for Railway Bridges, 1938 [17].

We can distinguish four periods of riverbank protection activities relevant for riverbank protection works today applied in Bangladesh. Two of these periods are before the People's Republic of Bangladesh was founded in 1971: 
(i). The early period is characterized by sporadic works for protecting towns or ferry terminuses, dating back to the 18th and 19th centuries and dominated by the large river crossings of prominent British railway engineers in parts reported in the previous section.

(ii). After independence from India in 1947, town protection appears to have become more frequent. However, documentation is scarce and difficult to trace. In the mid-1960s, the construction of flood embankments started (for example, $[33,34]$ ), which, in more recent times, are the driving factor for riverbank protection.

(iii). The times of the Flood Action Plan after 1990 brought two major developments: more systematic efforts to build riverbank protection suitable for the river environment, particularly the unruly Jamuna River, and the first attempts to protect longer river reaches against erosion [35-37].

(iv). Long guiding revetments began to be constructed to protect two irrigation schemes in the early 2000s [38]. This led to the development of cost-effective geobag revetments [15]. While widely applied today, specific aspects are still under a continuous development process, with technical refinements being piloted and applied [31]. New technologies are currently being tested including grout-filled jute mattresses [39].

Major works from the last two periods is summarized in Table 2. The majority of the works has been constructed on the Jamuna River, particularly on its right (western) bank due to its westward shift into the $175 \mathrm{~km}$ long Brahmaputra Right Embankment, resulting in embankment erosion and repeated reconstruction activities (nearly ten times in places).

Table 2. Summary of major riverbank protection schemes (PW = pilot works).

\begin{tabular}{ccccc}
\hline Location & Type of Works & $\begin{array}{c}\text { Implementation } \\
\text { Period }\end{array}$ & River & Material Used \\
\hline Sirajganj & Spur/revetment & 1940s until 2014 & Jamuna & Mixed materials \\
Chandpur & Spur/revetment & 1960s until 2019 & Padma/Lower Meghna & Mixed materials \\
Rajshahi & Spur/revetment & 1960s until 2010s & Ganges & Mixed materials \\
Kamarjani & Permeable spurs (PW) & 1994 until 1997 & Jamuna & Steel piles \\
Kalitola Groyne & Spur & 1980 s until 1998 & Jamuna & Mixed materials \\
Bahadurabad & Revetment (PW) & 1995 until 1998 & Jamuna & Mixed materials \\
Betil and Enayetpur & RCC spurs & $2001 / 02$ & Jamuna & Concrete blocks \\
PIRDP & Revetment & $2001-2008$ & Jamuna & Geobags \\
\hline
\end{tabular}

\subsection{The Early British Period (1750s until 1947)}

Earliest documented experience with riverbank protection dates back as far as the mid-1750s. Mr. LaTouche, in correspondence with Mr. Gales, reports about a hand-placed brick revetment in today's West Bengal, India, built, "to defend the barrack-square at Berhampur against the encroachment of the Bhagirati .... The barracks were built by Clive, shortly after the battle of Plassy, and the revetment, which seemed to have been put in about the same time, was still intact to his knowledge in 1904." This was some 150 years after construction [1]!

Railway engineers appear to have built most of the large riverbank protection works, often for ferry terminuses, and river training to maintain the increasing number of bridge crossings (see previous chapter on the Ganges crossing). The engineers at that time discussed three main aspects affecting the stability of the works. Shifting river planforms were a concern along with the associated degradation of a number of smaller rivers, such as the Baral. Additionally, engineers were concerned about riverbank erosion caused by scour, particularly at the end of the monsoon. Further, the engineers were focused on structure-specific problems that arose, they were concerned of whether revetments or spurs were more favorable.

The following quotes provide an overview of issues related to riverbank protection works:

"The difficulty of stopping this cutting action [related to river bends] was very great; groynes intended to turn the current were generally soon washed out, and even revetting along the bank line could not be 
altogether depended on, as the silt might run out through it, so that cutting might take place actually under the pitching." (Mr. LaTouche in correspondence with Mr. Gales reported in 1917 [1]).

Experience related to the protection of the ferry terminus at Gaolando is reported by two engineers:

"At the spur which was erected at Goalanda there was a bend scour of 180 feet on the up-stream side, but that did not affect the stability of the spur, the ultimate failure of the spur was due to the boring action of the whirlpool on the unprotected downstream side of the spur." (Sir Bandford Leslie in discussions with Mr. Gales, reported in 1917 [1]).

"When the river had (so to speak) made up its mind to move its bed it was not easily stopped. A spur costing nearly $£ 120,000$ had failed to keep the Ganges from washing away the station of Goalundo, at one time the river terminus of the Eastern Bengal State Railway; the whole of the buildings constituting the railway station and staff-quarters were swept into the river in a few days." (Mr. LaTouche in correspondence with Mr. Gales, reported in 1917 [1]).

\subsection{Town Protection and Embankments (Since 1947)}

After independence in 1947, the first initiatives were made in what was then East Pakistan to protect towns from erosion. At this time, the predecessor organization of today's BWDB, the East Pakistan Water and Power Development Authority (founded in 1958), was tasked to handle the erosion problems. Although there is little documentation available today of their efforts, it appears that they concentrated on three locations in the three main rivers [12]: Rajshahi on the left bank of the Ganges, Sirajganj at the right bank of the Jamuna, and Chandpur on the left bank of the Padma-Meghna confluence. Protective works were never really completed and consisted of continual efforts of construction and reconstruction applying different methods and technologies, often on an emergency basis. Even today, after many decades of continuous repair and adaptation, none of the three towns is guaranteed erosion free, even though all reached some level of stability.

The work at Sirajganj may serve as an example. The first work at Sirajganj was apparently performed during the British period as Sirajganj was an important ferry crossing [16]. The Bangladesh Guideline for Riverbank Protection reports in 2010 [12]:

"Sirajganj town protection work started in the British period. The work was strengthened in 1964 with brick mattressing, which was washed away in 1969. During the seventies more than $2 \mathrm{~km}$ revetment made of sand-cement blocks was built but was again destroyed during 1985 flood. At that time the protection was enhanced with the construction of the Ranigram Groyne at slightly upstream of the town on the right bank of the Jamuna river. The groyne was $854 \mathrm{~m}$ long (305 $\mathrm{m}$ in water) and involved $62,300 \mathrm{~m}^{3}$ of cc blocks. Army engineers were involved with BWDB personnel during the construction period. The construction was delayed due to fund problem and shortage of cc blocks. To cope with the situation, abandoned railway wagons had to be dumped at some places. This attempt was not, however, successful. In May 1986, a larger damage of the structure occurred whose value was estimated at about BDT 1 crore. Both the groyne and the revetment, which were provided with concrete block armour but no filter layer, were subjected to regular damages during monsoon. To increase safety factor against anticipated severe erosion hazard, the Sirajganj Hard Point was reconstructed integrating the groyne and the revetment during the period 1996-1998 under River Bank Protection Project (RBPP)." The Hard Point failed repeatedly with major investments for reconstruction and adaptation in 1999, 2002, 2005-2012, and finally 2013-2014.

Interventions were by and large not successful. The rapid widening of the Jamuna and Padma Rivers from the mid-1970s, a lack of understanding of the governing river processes and financing constraints lead to "fire-fighting". Sometimes desperate measures were applied, such as dumping railway cars as riverbank protection. In the early 1990s, consulting teams attempted to investigate the performance of the work established earlier and identify failure causes. The Consulting Consortium 
Flood Action Plan (FAP) 21/22 concluded in 1993: “ ... hardly any or even contradictory information is available for the past failures, as continuous monitoring is lacking. ... One main factor for failure of bank protection structures, which is repeated in every damage report again and again, is the shortage of funds for timely and proper execution as per design. Most of the possible deficiencies may be traced back to these two basic shortcomings, ultimately resulting in a wastage of the whole investment... It may be summarized that damages are likely due to 3 reasons and a combination thereof:

1. Lack of timely allocation of funds;

2. Use of unsuitable materials and construction methods, and

3. Inadequate designs due to lack of research work (morphological understanding, hydrodynamic forces, soil properties etc.)" [40].

Acknowledging the population increase during the early 1950, shortly after independence, the UNDP ("Krug Mission") identified the need for systematic flood protection to provide more controlled conditions for higher yielding rice varieties, especially in the Northwestern portion of the country (the "bread basket of Bangladesh"). This resulted in a massive embankment construction program starting with the Brahmaputra Right Embankment from the mid-1960s [34]. The embankment runs over some $175 \mathrm{~km}$ from the Teesta to the Hurashagar rivers along the right bank. During the 1980s embankments from the Hurashagar to the Ganges and from the Teesta to the north at Kurigram were built, completely embanking the approximately $250 \mathrm{~km}$ long right bank. These embankments came under increasing erosional threat and had to be reconstructed in places multiple times. Over time, the embankment line lost more and more of its set-back distance. In the most erosion prone reach, the set-back distance reduced from $1300 \mathrm{~m}$ in the early $1970 \mathrm{~s}$ to $650 \mathrm{~m}$ in the mid-1990s, and finally to $350 \mathrm{~m}$ in 2014 [41]. The remaining setback distance is coming close to the annual average erosion rate. The high number of embankment breaches highlighted the need for an economic solution for protecting longer stretches of riverbank.

\subsection{The Flood Action Plan (1990s)}

After two successive record floods in 1987 and 1988, the Government took up the Flood Action Plan (FAP) coordinated by the World Bank. The 26 components looked at the systematic development of the water resources in Bangladesh, such as riverbank protection and river training $[37,40,42]$. Significantly, some of the initiators recognized the need for piloting different options to arrive at work suitable for the difficult conditions in the main rivers, as well as the importance of monitoring the river.

The spur concept governed this period and got extended towards more systematic protection along longer river reaches. In terms of technologies, there was broad agreement to use concrete blocks as surrogate for the unavailable rock in Bangladesh, as well as to accept dredging limitations and depend on self-launching aprons to protect against toe scour. Alternatives ranged from a series of permeable spurs with the purpose of reducing near bank flow velocities and attract deposition [40], somewhat T-shaped "hard points" [37] developed shortly thereafter, and finally RCC spurs attempting to push the river away from the bank line and reducing the cost of the "hard points". These three alternatives are explained in more detail below:

(i). Permeable spurs to reduce the flow velocities: The FAP 21 bank protection pilot project developed this concept between 1991 and 1992 and implemented a series of seven permeable groynes just upstream of the Garghot River at Gaibandha from 1994 until 1996 [40]. The initial works consisted of six permeable spurs, typically spaced at 200 to $300 \mathrm{~m}$, protecting some $2 \mathrm{~km}$ of riverbank. The pile rows were connected to the floodplain through cofferdams.

During the first flood in 1995, the cofferdams eroded in places due to deep downstream scouring (refer to Sir Bradford Leslie's quote on the Gaolando spur in Section 3.1) and were replaced by additionally permeable piles (Figure 5). There is some controversy about whether or not the spurs work because of the lack of deep channels in the vicinity of the structure. On the one hand, this may imply that the structures are inducing sedimentation; however, this could be 
a result of the natural river morphology as this reach is extremely morphologically active with a high braiding index. Nevertheless, these structures are not advantageous for navigation purposes.

(ii). "Hard points" spaced along the existing riverbank: Hard points were developed as an attempt for an economic solution to the increasing erosion of the Brahmaputra Right Embankment during the 1980s (Section 3.2). The planners of the Master Plan Report for protecting the Brahmaputra Right Embankment arrived at far-spaced, short $(600 \mathrm{~m})$, revetments to protect sections of the riverbank, termed "hard points" [37] (Figures 6 and 7). The revetments are connected to the flood embankment over the floodplain with a cross bar. The land in between adjacent hard points was allowed to be eroded, requiring the retirement of the flood embankments. As important construction element, hard points introduced dredging and systematic underwater scuba-diving investigations to riverbank protection.

The case of riverbank protection alongside $14 \mathrm{~km}$ of riverbanks with the approximately $2 \mathrm{~km}$ long hard point of Sirajgnaj Town Protection in the center demonstrates the limitations of this concept and the difficulties with widely spaced disaggregate protection. As mentioned in Section 3.2, the modern work at Sirajganj started with the construction of Ranigram Groyne in the mid-1980s (Figure 6). However, the groynes could not protect the downstream town effectively. Therefore, Ranigram Groyne was incorporated into the $2 \mathrm{~km}$ long hard point built during the second half of the 1990s.

This hard point served the dual function as the starting point for funneling the Jamuna River towards the $5 \mathrm{~km}$ wide Jamuna bridge crossing and to protect the growing town. The upstream area was believed to be protected against outflanking flow through Sailabari Groyne built in 1978 . Downstream, the west guide bund of the Jamuna bridge crossing shifted the riverbank $4 \mathrm{~km}$ into the river corridor towards the east.

During the bridge studies, a second groyne was initially considered necessary between Sirajganj town protection and the west guide bund but dropped after additional confirmation about worst-case outflanking scenarios. The Sirajganj town protection was completed in 1998 and experienced its first flood with outflanking flows.

The 1998 record flood destroyed the upstream termination, around the head of the old Ranigram Groyne. After reconstruction in 1999, the next major change occurred when Sailabari Groyne failed in 2005. Consequently, the upstream protective flood embankment eroded, and the town was devastated during the high 2007 flood. To secure the reconstructed embankment, the BWDB built an $8 \mathrm{~km}$ concrete block revetment along the outflanked bank line upstream of the town. However, the embayment filled in quickly over the coming years. Erosion occurred downstream between the town and the west guide bund around 2006 and 2012. While the erosion was less than the design case [29], the BWDB intervened through the capital pilot dredging project in 2012. The secondary purpose of this intervention was the reclamation of land for industrial development. In addition, the capital pilot dredging project changed the channel pattern from upstream of the town to downstream of the bridge crossing by dredging a new channel. As part of the dredging, two cross bars each were built over the approximately $6 \mathrm{~km}$ long outflanked areas upstream and downstream to reclaim the eroded land. The BWDB adapted the town protection around 2014, as the apron systematically failed when reaching just beyond design level. To this end, approximately $110,000 \mathrm{~m}^{3}$ of rock was placed systematically over the launched apron and building an additional apron in front (more than $55 \mathrm{~m}^{3} / \mathrm{m}$ ) at an equivalent cost of approximately USD 9.5 million. The last work on the cross bars was completed in 2019.

(iii). Reinforced cement concrete (RCC) spurs pushing the river away from the bank: Due to the high cost of the "hard points", the BWDB started developing and building a more cost-effective solution, termed RCC spurs, in parallel to the development of the hard point concept, from approximately 1996. The RCC spurs (Figure 8) were designed to close developing bank line channels through an earthen dam or shank protruding up to a kilometer into the river. The fortified head of the spurs was built on an adjacent char and consist of a $150 \mathrm{~m}$ long concrete wall carried by two 
rows of $25 \mathrm{~m}$ long bored piles and protected against scouring by an approximately $20 \mathrm{~m}$ wide radial apron made of concrete blocks. The spur heads were expected to deflect the river and allow siltation of the bankline channel in between the shanks. Typically, two spurs were built several kilometers apart.

The concept of RCC spurs is superior to the "hard point" concept as it turns riverbank erosion into floodplain reclamation. The performance, however, was dismal, as the spurs failed rapidly when under attack. The combination of unconsolidated soils, lack of a filter layer and rapid scouring events triggered flow slides and lead to widescale failure of the structures. In total, 18 spurs were built in the Jamuna, 9 in the Ganges and 9 in smaller rivers such as the Teesta. The total investment amounted to some USD 125 million (in 2019 prices), with an average cost of approximately USD 5 million per spur in the Jamuna, nearly 3 million for the Ganges and 1.2 million for the smaller rivers. In total, 12 spurs in the Jamuna and 4 in the Ganges were destroyed or partly destroyed not even two decades after initial construction and the concept has substantially failed.

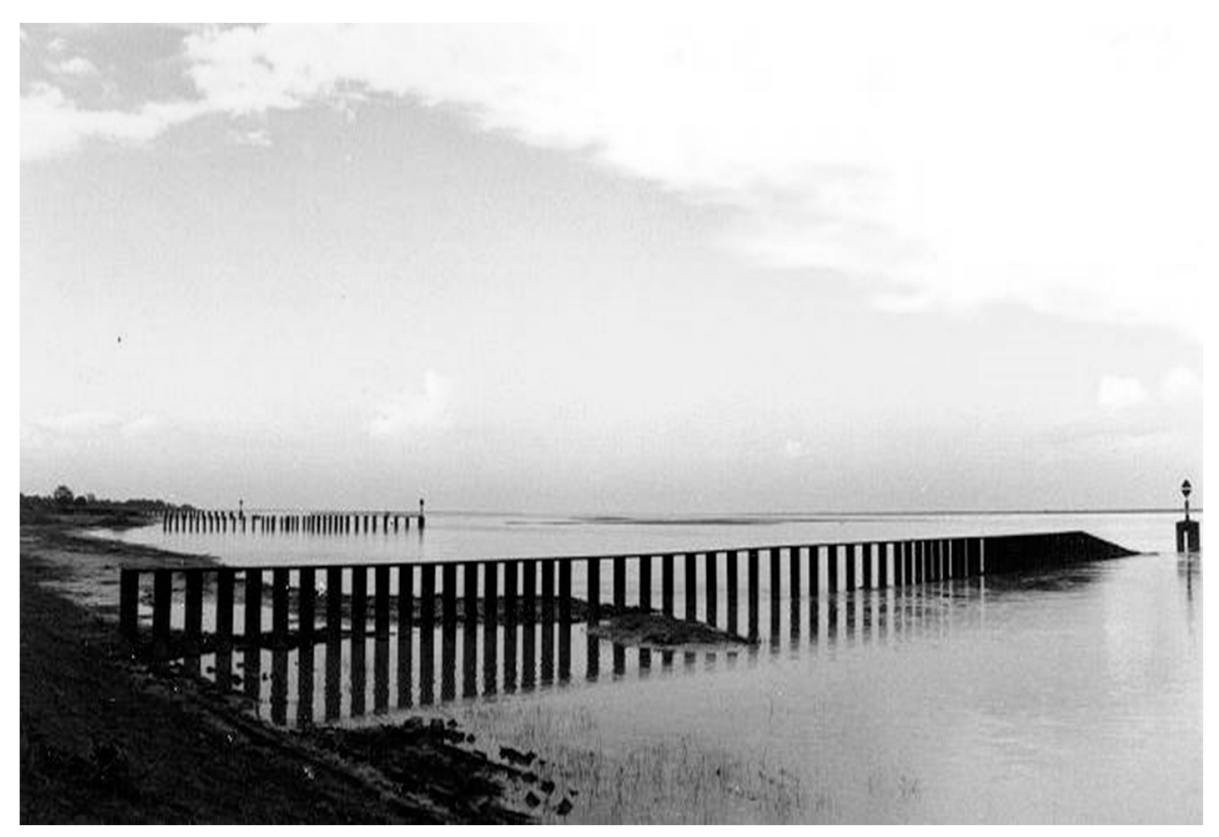

Figure 5. The approximately $200 \mathrm{~m}$ long central spur at Kamarjani during the 1997 flood (the embankment slope is on the left side of the photo) (photo: author). 


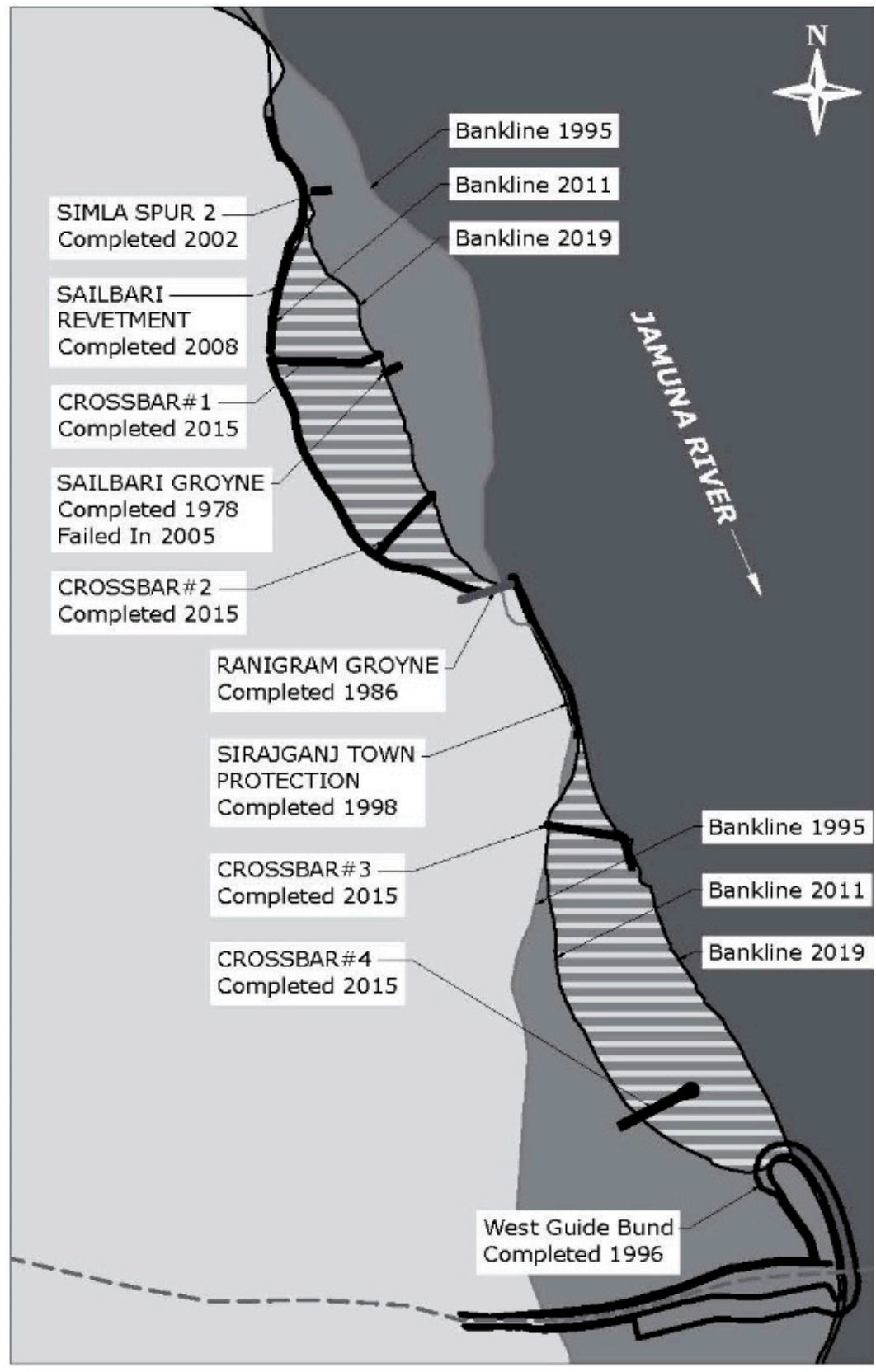

Figure 6. Forty years of developments at Sirajganj. 


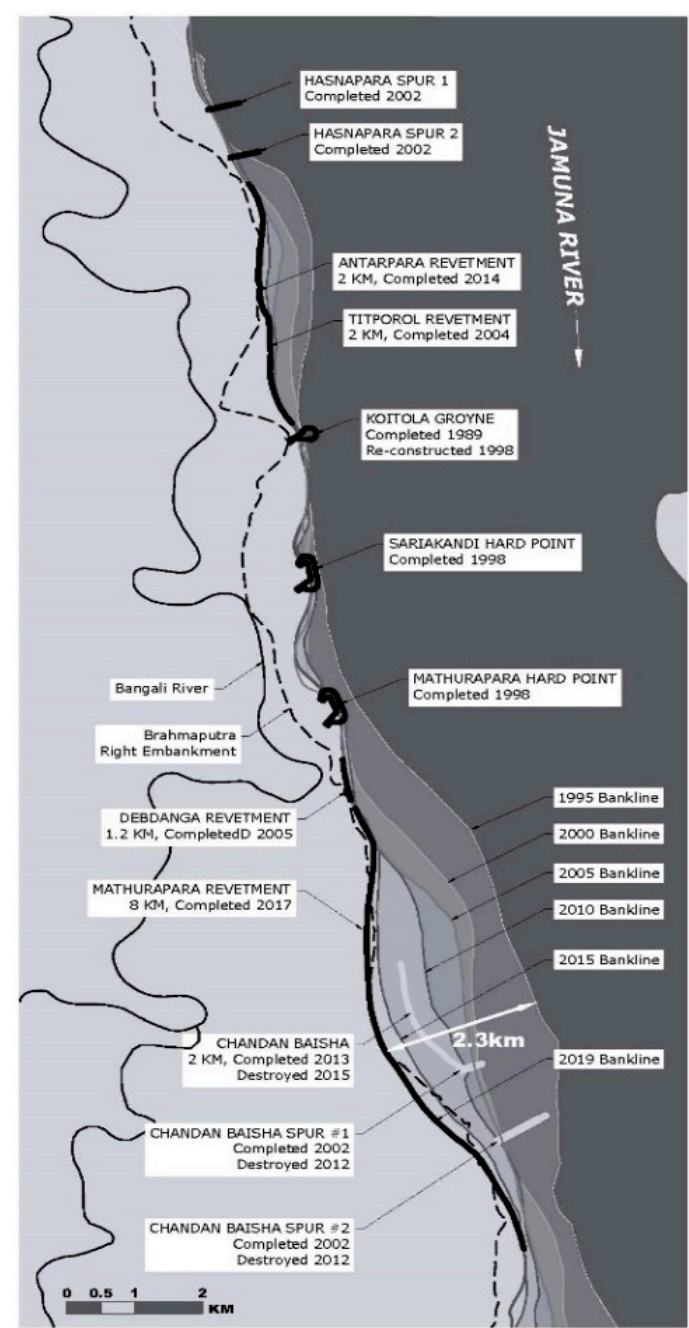

(a)

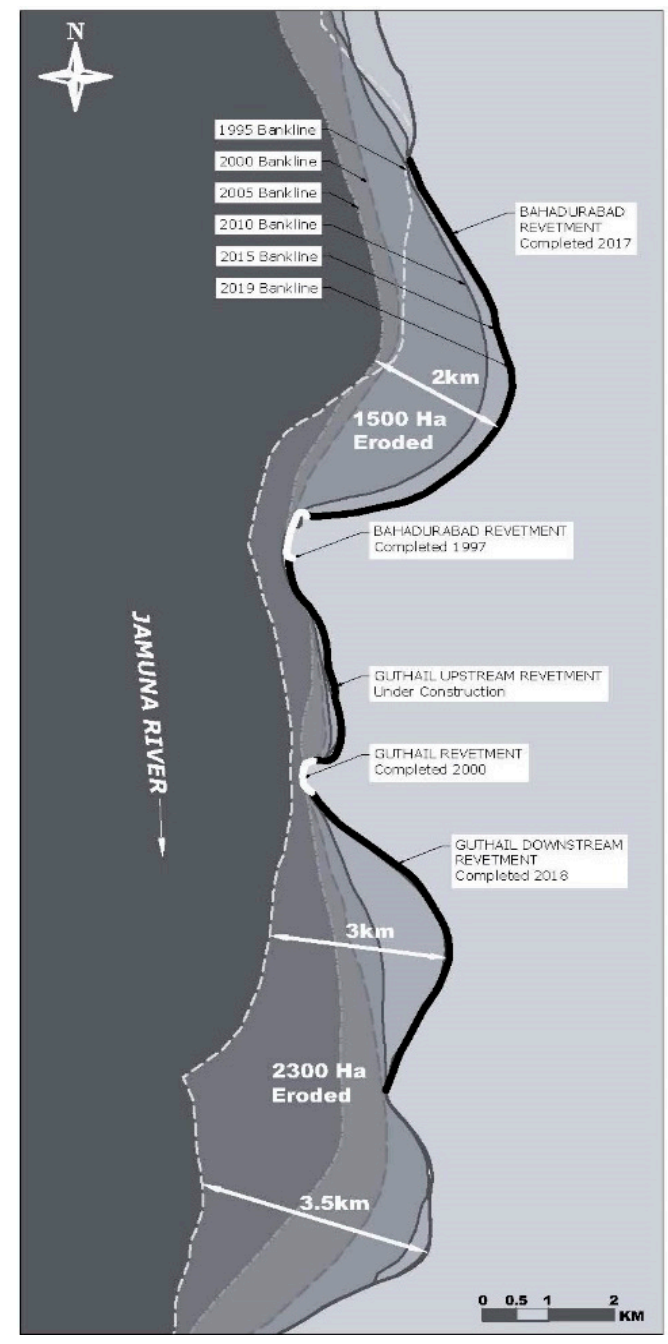

(b)

Figure 7. (a) "Hard point" concept at Sariakandi and Mathurapara with additional protection over 25 years. (b) Erosion around "hard points" at Bahadurabad and Guthail over 25 year.

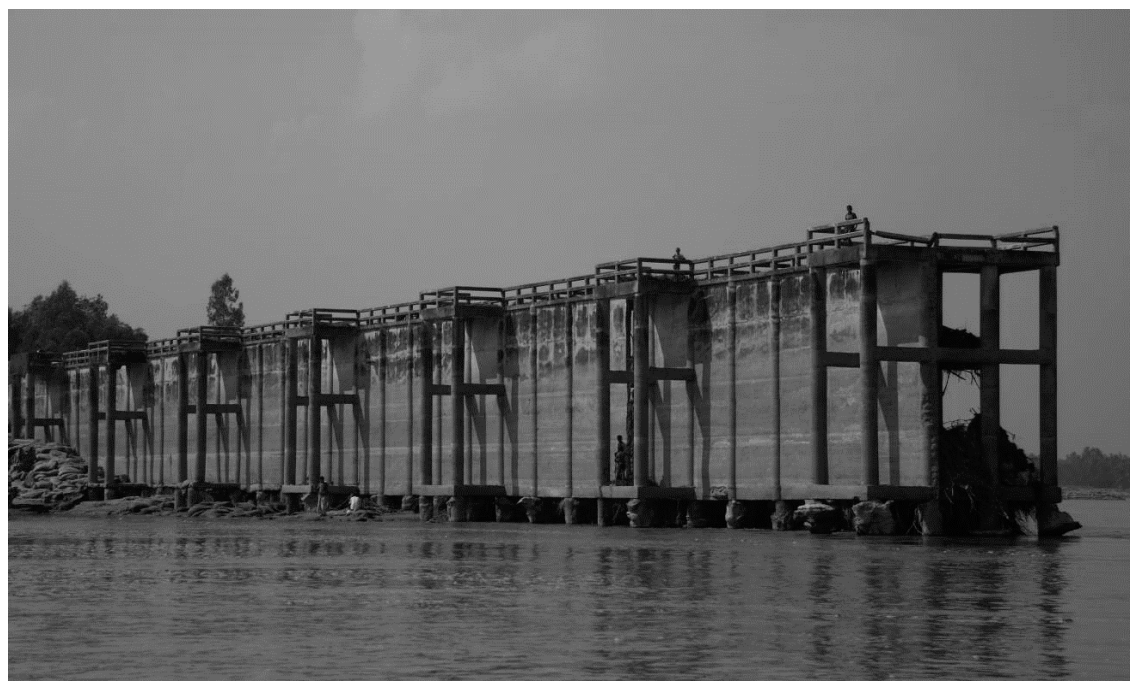

Figure 8. Shimla \#2 RCC spur in November 2019-part of the end section has broken off and the protection has settled allowing flow underneath the wall (photo: author). 


\subsection{Long Reach Protection (Since Early 2000s)}

During the early 2000s, the BWDB used the experience from earlier work to develop a new technology, geobag revetments $[11,13]$. The systematic analysis of past work combined with systematic scuba-diving investigations provided three fundamental insights:

(i). There is no stable riverbank protection in Bangladesh without adaptation and maintenance works.

(ii). Scour depths at revetments are approximately half that of protruding structures such as spurs or "hard points" and therefore are less likely to fail [3,43].

(iii). Toe protection aprons work only under limited conditions. Aprons (a) must sit on consolidated soils (stable at angles of $1 \mathrm{~V}: 2 \mathrm{H}$ ), (b) launch only in a single layer (the launched apron is prone to winnowing failure and consequently requires upgrading to multiple layer thickness), (c) are susceptible to flow slides during rapid scouring and therefore should be made as wide as possible.

These conclusions, particularly the realization about the limitations of aprons, led to the development of an adaptive approach to riverbank protection. All riverbank protections depend on imperfectly launching aprons as the dredging depth is limited. Consequently, all work requires upgrading or adapting the aprons after launching to cover the newly scoured, deeper part of the riverbank. Multi-year adaptation contracts for river reaches are the most practical solution. The adaptive approach will be further discussed in Section 4 .

A key driver for the use of geobags dates backs to the independence from Great Britain and the separation in 1947. For Bangladesh, independence also meant the loss of access to all quarries and rock. Over the following five decades, designers were forced to develop and use alternatives-first bricks, then concrete blocks, and finally geobags. Geobags had been used in Bangladesh sporadically and in a limited way since the end of the 1980s (for example [40,44]). Building on available historical experience, economically affordable geobag revetments were developed through a systematic design development process from 2004 to 2006 [38]. Further, standards were set for the longevity and durability of the bags $[3,13]$. Thompson et al. [15] provide further details about the development of geobag revetments in Bangladesh and Assam, India.

Fundamental to the success was a planning and construction process incorporating multiple activities (Figure 9). Location and length were selected based on satellite prediction (for example $[45,46]$ ) and confirmed during the flood season through large-scale river surveys. The fund allocation was flexible through multi-year contracts. The envisaged goal was to budget riverbank protection annually based on priorities established through erosion prediction. The annual budget (termed Annual Development Program) is typically made in April and May and can incorporate findings from the annual erosion prediction. The work was implemented flexibly, based on surveys immediately prior to construction, to provide full protection to the actual bed level and a suitable apron to address peak scour rates. After construction, the works were permanently monitored and adapted in areas where deep scouring had occurred. Figure 10 shows the further developed principle of phased construction to deeper levels (for a wide apron concept). Additional insight on geobag performance was gained from systematic scuba-diving investigations [47]. Diving investigations provide additional information even high resolution surveys cannot provide, such as the movability of protective elements, the shape and size of voids between elements, the constitution of the surface for example in terms of growth of lifeforms, the integrity of the seams of geobags, and also allow taking a "look" under the surface layer to some extent.

Initially, the BWDB tested concrete block revetments in parallel to the development of the long-guiding geobag revetments in the early 2000s. However, the constructed revetments experienced some failures shortly after construction and were repaired using both geobags and concrete blocks. Given the much higher kilometer cost of concrete blocks compared to geobags, the BWDB preferred geobag revetments after 2005. 


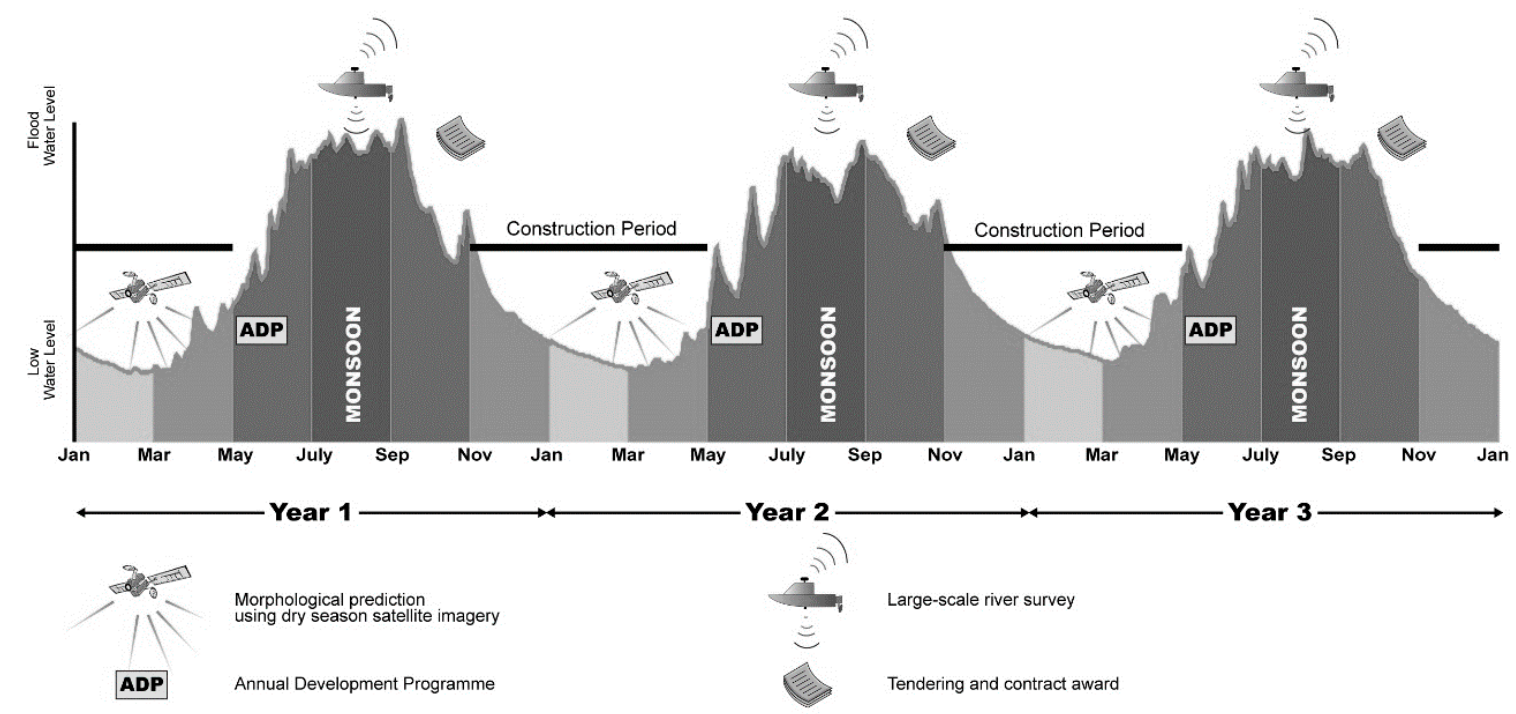

Figure 9. Elements of a broad design development process [49].

The application of geobag revetments has been very successful. More than $45 \mathrm{~km}$ of geobag revetments were systematically built between 2004 and 2011 and from 2016 until 2018 under two Asian Development Bank (ADB) supported projects [38,48]. The per kilometer cost remains less than USD 3 million (2019 cost), and with that the work remains the most cost-effective technology available. Implementation progress is high. While initially some 4 to $5 \mathrm{~km}$ of underwater revetments were constructed per season, $16 \mathrm{~km}$ could be completed in 2016. The cost reduction by using sand-filled geobags enabled the construction of long revetments, guiding the flow parallel to the riverbank and therefore avoiding deep sudden scouring and associated geotechnical slope instability. While no land was gained, a more benign and less erosive flow pattern could be obtained, and no further land would be lost. The first long revetments in the lower Jamuna have started demonstrably stabilizing river reaches by providing more stable, deeper channels, attracting the flow repeatedly to the same location. In 2011, the largest river crossing ever built, the Padma Bridge [3], adopted the adaptive approach for its river training works (see Section 2). 


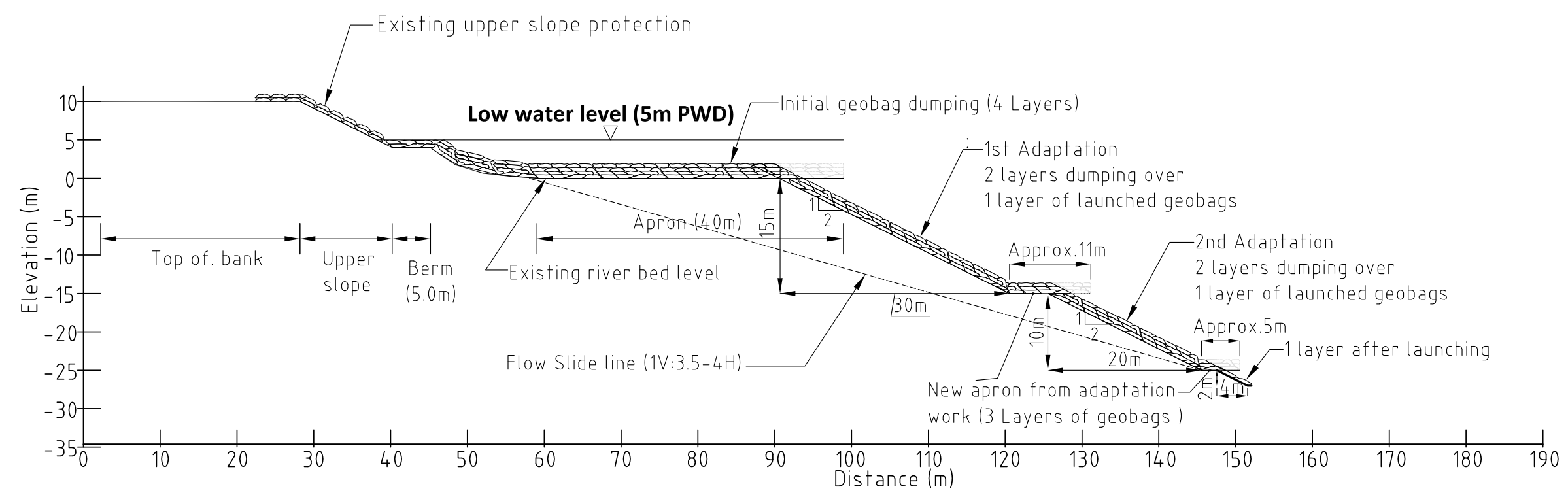

Figure 10. Adaptive riverbank protection for a wide apron and consolidated bank and unconsolidated bed material. 


\section{Experience and Lessons Learned}

“What has already been done at Dibrugarh deserves to be made known throughout India, and indeed the whole world. It is a story of challenge taken and met with firm determination, hard work, and all round cooperation leading to success." Jawaharlal Nehru, Prime Minister of India on 29 August 1955 after completion of the Dibrugarh Town Protection works in upper Assam within one dry season [50]. (Dibrugarhis located on the Brahmaputra River some $600 \mathrm{~km}$ upstream from the Bangladesh border. Parts of the town eroded as a consequence of the widening of the Brahmaputra after the Great Assam Earthquake in 1950. During the second dry season a 6 mile long flood embankment and drain were added. The work still protects the town today.)

\subsection{Knowledge-Based Development Drives Change}

A period of intensive knowledge-based development can produce new technologies and trigger significant changes. The field of riverbank protection in Bangladesh is an excellent example of this. The efforts made to gain a better understanding of the underlying river processes of one of the most complex river systems in the world enabled the idea of a safe and stable flood plain to materialize. Studying the largest, braided, sand-bed river in the world, the Jamuna, is no small task. Over a period of two decades, intense study focused on why the river was widening (Figure 11). This period commenced with the Flood Action Plan of the 1990s and concluded with Dr. Sarker's dissertation on the Brahmaputra sediment wave in 2008 [6] and the morphological studies for the Padma Multipurpose Bridge in 2010 [51].

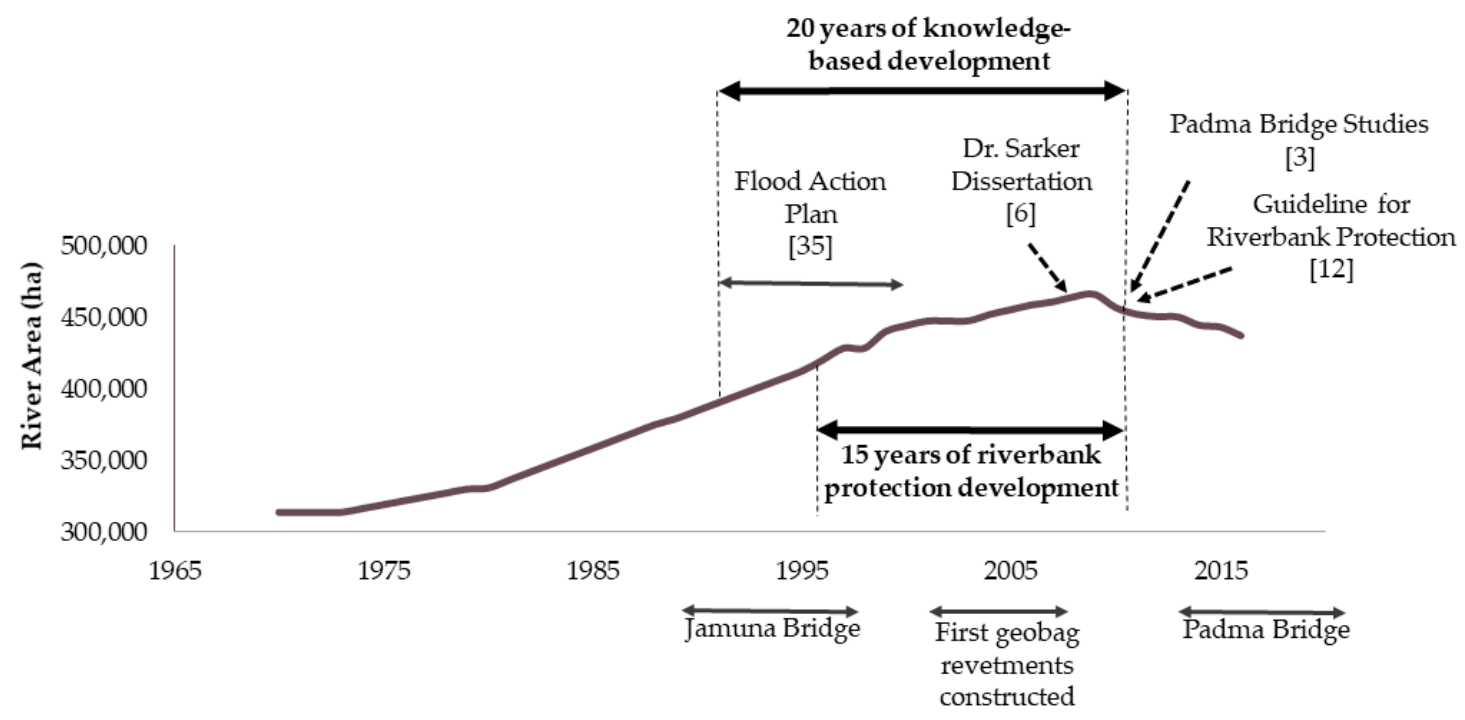

Figure 11. Knowledge-based development in Bangladesh.

In parallel to this period of study, construction of closely monitored works further contributed to the knowledge base, which, in turn, further improved the constructed works. Notable works include the construction of permeable spurs near Gaibandha under component 21 of the FAP in early 1995 or the construction of the Jamuna Multipurpose Bridge, independently designed from the FAP (Figure 11). The combined experience was summarized in the Guideline for Riverbank Protection, approved by the BWDB in 2010 [12].

Experience with the performance of the works of the FAP during the 1990s led to the design of the low-cost, easily constructible geobag revetments in the early 2000s. This new technology has made it possible to envision a river stabilized in a holistic manner, rather than limited to a few locations of high value infrastructure. The geobag revetments at Bera and upstream of Chandpur constructed 
between 2004 and 2008 have performed well for 15 years with minimal maintenance. This is half of their economic design life. The cost of riverbank protection has reduced from up to USD 30 million per kilometer for earlier solutions (Sirajganj Town Protection) in mid-1990 prices to USD 3 million per kilometer in 2020 prices. These geobag revetments have been built systematically with ADB support and have provided safety and security to the large populations that live alongside the river $[38,48]$.

The intensive development process occurred during a period of widening for the Jamuna River. Today, it appears that the widening trend is reversing, which creates the unique opportunity to work with the river in narrowing its corridor and reclaim valuable floodplain land. To do this, scientists, engineers, and policy makers are continuing to broaden their understanding of the rivers in Bangladesh in order to further improve and optimize the designs for systematic stabilization measures to be implemented. The following sections summarize the key experience and lessons we have learned so far.

\subsection{Revetments Are Superior to Spurs}

Interestingly, the realization of the superiority of revetments to spurs occurred two times: first, during the development of bridge crossings in the 19th century and then again in the last three decades of the 20th century-approximately 110 years later! In the 21st century, the notion that spurs successfully protect the downstream banks in a large braided river fell out of favor for a number of reasons.

Firstly, newly built protruding works, for example at Sirajganj and Kalitola Groyne, failed repeatedly during angular flow attack due to sudden deep scouring. The annual scour for protrusions is double that for revetments. Hotopp et al. [43] provided a first analysis of different scour rates for periods up to a flood season ( 90 days) for protrusions (spurs) and revetments.

Secondly, there were great improvements in the development of the underwater protection. Over time, effective filter layers were introduced. In the 1800s, crushed stones and clay layers were used [17]. This changed in the early 1990s when geotextile filters were first introduced for the works at the permeable spurs near Gaibanda (refer to Section 3) [40]. Ten years later, geotextile bag revetments went one step further by combining the filter properties with the weight of the elements in a single cover layer [52].

Thirdly, geobag revetments have clear cost and sustainability advantages over hard points and spurs. Table 3 compares the kilometer cost for different works. The dramatic reduction in cost enabled the abandonment of the concept of disaggregate short bank protection (groynes, spurs, hard points).

Table 3. Comparison of cost for Sirajganj "hard point", Betil and Enayetpur RCC spurs, and Kaitola geobag revetment.

\begin{tabular}{cccc}
\hline & Sirajganj & $\begin{array}{c}\text { Betil and } \\
\text { Enayetpur }\end{array}$ & PIRDP, Kaitola \\
\hline Type of works & $\begin{array}{c}\text { Hard } \\
\text { point }\end{array}$ & RCC spurs & Geobag revetment \\
\hline Design and construction phase & $1990 \mathrm{~s}$ & $1990 \mathrm{~s} / 2000 \mathrm{~s}$ & $2000 \mathrm{~s}$ \\
\hline Construction completed & 1998 & 2002 & 2004 under water \\
\hline $\begin{array}{c}\text { Adaptation and reconstruction during first 10 years } \\
\text { Kilometer cost (in BDT million), initial investment } \\
\text { (and bracketed values in 2019 prices) }\end{array}$ & $\begin{array}{c}2218 \\
(6780)\end{array}$ & $1109(2785)$ & 0 times \\
\hline Adaptation and repair: In percent of construction cost & $30 \%$ & $119(276)$ \\
\hline
\end{tabular}

Fourthly, revetments stabilize the river course. The deepest scour in the Jamuna in the mid-1980s was associated with confluences. Today, in concurrence with the increasing amount of riverbank protection, the deep scour has shifted to outer bends where revetments have been built. This change 
has led to a more stable channel pattern and provides the backbone for a more navigable river. The most recent river stabilization plan [16] recommends the use of geobag revetments for bend control of a more sinuous channel pattern.

While the stabilizing effects of revetments were known from modelling, it took time to confirm this. Mosselman [53] writes related to model studies: “. . the width of straight rivers cannot be stabilized by a discontinuous bank protection... This does not imply, however, that the width of river bends cannot be stabilized by protecting the outer bank only, nor it imply that channel migration cannot be stopped by a discontinuous protection. Friedkin (1945) concludes from laboratory experiments that channel migration can be checked by isolated resistant points, but that this method is not recommendable as it induces deep scour holes and sharp bends. He advises to stabilize longer stretches that begin at a stable bank section and extend downstream. If the bank immediately upstream is unstable, the protection has adverse effects that are similar to those of isolated resistant points. The location of the downstream end of the protection has less influence."

The stabilizing effects of revetments in the river can be understood by comparison of two examples. At Bahadurabad and Guthail, two pilot revetments were built $3.5 \mathrm{~km}$ apart. These were short revetments similar to hard points. Figure 7 demonstrates the bank line development, showing that without multiple relatively closely spaced works, there is very little influence on the river pattern (and protective effect on the adjacent floodplain). Meanwhile, the channel development during the first four years after construction alongside a new revetment near Tangail (Chauhali) had a stabilizing influence on the river morphology (Figure 12). The new revetment lead to substantial scour during the first two years, with approximately $15 \mathrm{~m}$ scouring over nearly $3 \mathrm{~km}$ during the first flood after construction. The line from September 2015 (between +2 and +3) indicates that eroding channels are not deep at all (in this case only 2 to $3 \mathrm{~m}$ below low water level), but deepen rapidly in response to protective works. Overall substantial volumes of sediment eroded over a length of $5 \mathrm{~km}$ and measured in a $250 \mathrm{~m}$ wide strip from the bank line (Table 4). After 2017, severe riverbank erosion upstream moved approximately half of the earlier eroded sediment back into the bank line channel. The scour observed at Chauhali is an example of why adaptation works are necessary.

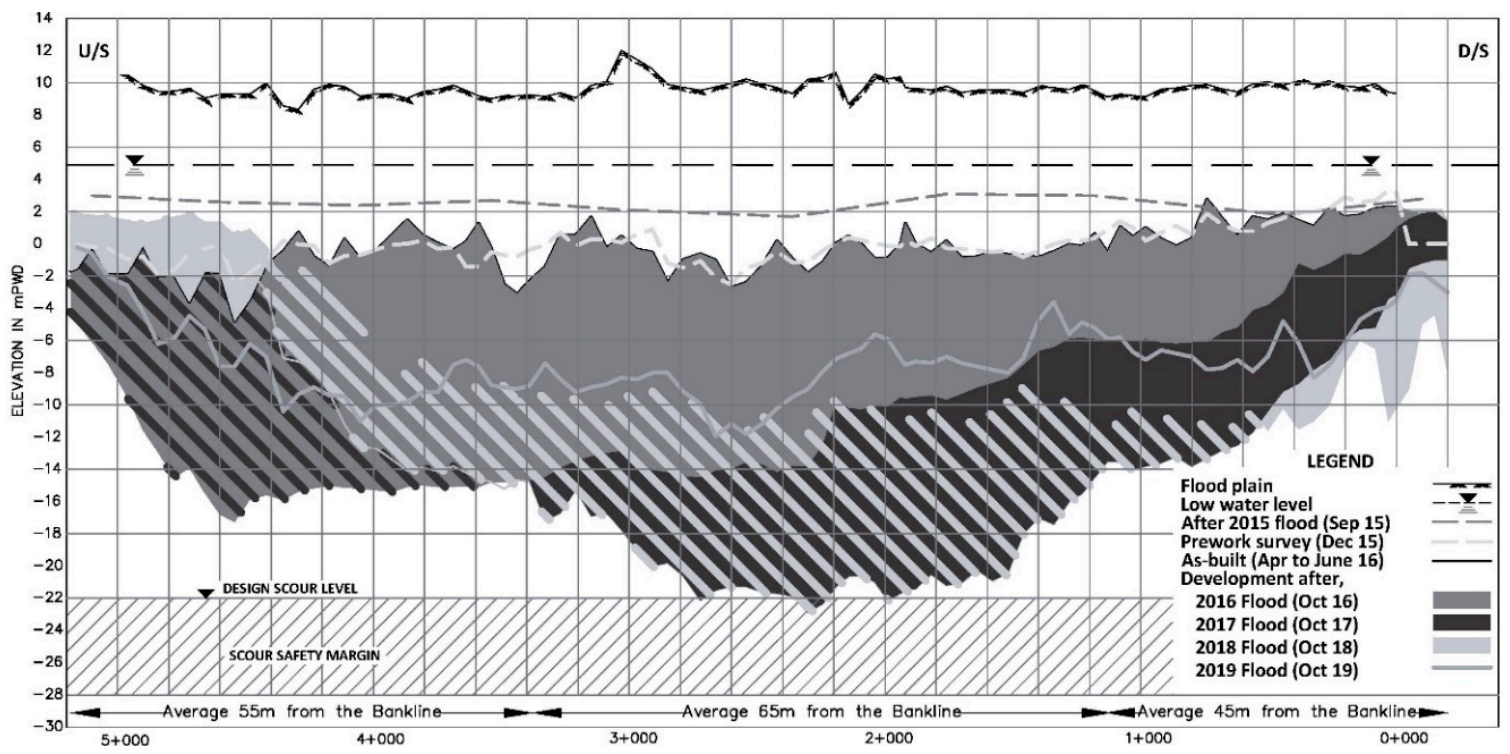

Figure 12. Long section along $5 \mathrm{~km}$ of revetment at Chauhali Tangail with scour development along the apron during the first four years after construction (2016 to 2019) (image updated from [15]).

Table 4. Annual sediment movement along the $5 \mathrm{~km}$ long revetment at Chauhali, Tangail.

\begin{tabular}{lcccc}
\hline Date (Oct-Oct) & 2015 to 2016 & 2016 to 2017 & 2017 to 2018 & 2018 to 2019 \\
\hline Difference $\left[\mathrm{m}^{3}\right]$ & $-5,200,000$ & $-2,700,000$ & $+3,500,000$ & \pm 0 \\
\hline
\end{tabular}


The combined experience of modelling and prototype data tilts the balance clearly in favor of revetments as preferred approach to protect riverbanks against erosion and stabilize the river course. This notwithstanding, low spurs might provide advantages in support of sustaining navigation channels in future after a stable planform has been achieved.

\subsection{Learning by Doing-A Flexible Design Approach for Dynamic Rivers}

The development of riverbank protection in Bangladesh is strongly characterized by "trial and error" or "learning by doing" as was already recognized in the 1960s (for example [54]). This approach was driven by the necessity to protect important locations despite repeated failures of the designed works. As the risk of failure is always present in the mighty rivers of Bangladesh, design techniques have traditionally steered towards structures that are immune from local failures and need little or no maintenance (because funds may not be available for future maintenance). This design ideology does not fare well in such unpredictable, dynamic environments, such as the Jamuna River. Rather, the design philosophy must be flexible and adapt over time, accounting for the plethora of uncertainties and adjusting to the river's present conditions. This has been coined as the "learning by doing" approach.

"Learning by doing" involves a design development process based on a good understanding of the river behavior, site specific investigations (subsoil investigations, physical and numerical modelling), pilot works, continued monitoring and evaluation and finally the adjustment of the designs.

A number of large, donor-financed projects acknowledged substantial, non-quantifiable uncertainties by incorporating the piloting (for example [36]). The planners understood that there was no design that could guarantee protection over extended periods of time under the large uncertainties of the Jamuna River environment. Piloting provides the advantage that new ideas can be tested without the risk of large-scale failure from unforeseen consequences. Later, geobag revetments were also developed in part through pilot works [38]. Recently, grout-filled jute mattresses as an alternative wave protection have been pilot tested [39]. The Padma Bridge river training works contractors utilized a trial section to test the construction methodology of the works. In the future, it would be advantageous to test new designs for the transition zone between the hard material above low water level to the geobag protection below low water level. The current design, likely in combination with locally weaker zones or localized erosion, leads to regular sliding of the upper slope protection (Figure 13).

Other elements to reduce the risk are the use of physical hydraulic and numerical models, both well established in Bangladesh. The use of physical hydraulic modelling in the region goes back to British India in the 1920s with strong involvement of Claude Cavendish Inglis [55]. Major research associated with river training works was conducted during the 1930s after the failure of the right guide bund at Hardinge Bridge (refer to Section 2). The Hardinge Bridge model in the 1930s [32] created the first stir (discussion and correspondence reported by Gales in 1938 in [17]), when the model findings contradicted believes about apron performance published over the preceding half century $([17,18])$. Today, the River Research Institute in Faridpur is tasked with physical hydraulic modelling. Meanwhile, numerical modelling originates from the Flood Action Plan with the establishment of the Surface Water Modelling Center. Today, it is known as the Institute for Water Modelling and includes substantial survey capacity to provide input data to the models.

While appreciating the importance of "learning by doing", existing risk mitigation measures help focus the design development process. Large-scale and longer-term river changes compounding the uncertainties can be excluded when applying predictive tools. While these have limited time horizons, their application still reduces the risk. Morphological predictions can only be made one or two years into the futures [46,56]. Shorter-term predictions are more accurate, with techniques being employed such as float tracks during the flood season indicating dry season channels [40]. Unfortunately, it typically takes more than two years for the Government to approve projects and allocate funds. This means that there remains the residual risk from rare, exceptional floods that could impact on the siting of the works. 
Today, flexible design practices are beginning to be accepted in Bangladesh. The Bangladesh Delta Plan 2100, approved by the government in September 2018, provides a country-wide, high-level plan to water management. The Delta Plan introduces the concept of Adaptive Delta Management, basically acknowledging that there are still unknowns and that it is impossible to determine the future and prepare concrete plans. The plan strongly advocates a "learning by doing" approach.

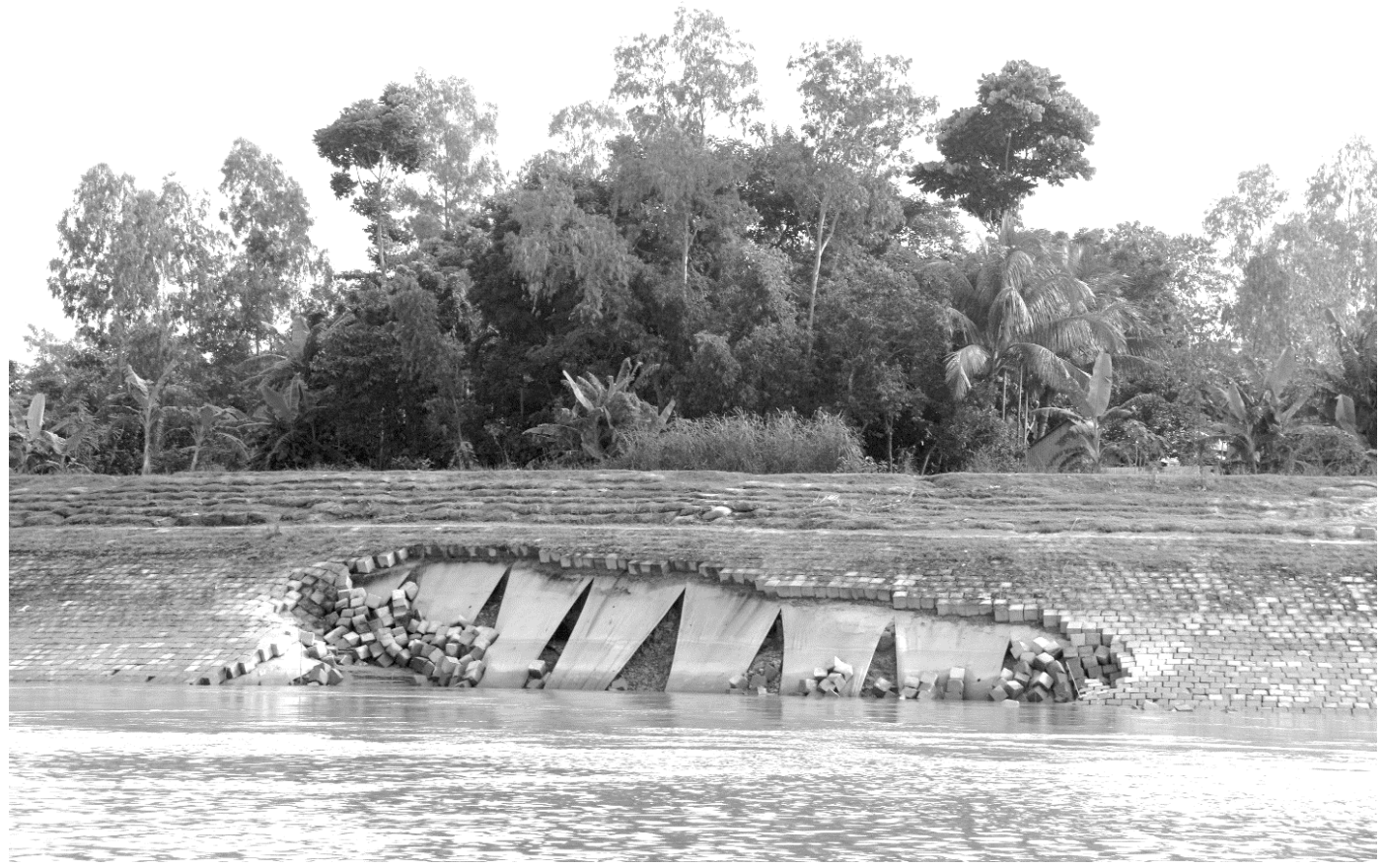

Figure 13. Typical revetment damage mostly occurring at the downstream half of a protected river bend, here seen at Bahadurabad near Jamalpur in November 2019, (photo author).

\subsection{The World of Aprons-A Fine Line between Success and Failure}

Bangladesh has driven the understanding of the performance of aprons in sand-bed rivers. The extreme river conditions dictate their use, as even the biggest cutter suction head dredgers (approximately $35 \mathrm{~m}$ dredging depth) cannot provide defined slopes to the deepest scour levels, recorded to surpass $70 \mathrm{~m}$ measured from low water level. Systematic apron studies started in the early 1990s and continued until 2016 (for example [36,57-59]).

The widely used aprons (launching aprons, falling aprons) only provide temporary protection. The aprons self-deploy when coming under erosive attack and form a single separation layer between the fine, easily erodible soils and turbulent, fast-flowing water. After launching, additionally protective material is required. The launching process is defined by the two geotechnical parameters angle of repose of the launching material and stable slope angles of the underlying sandy soils during scouring. The compromise angle between both is $1 \mathrm{~V}: 2 \mathrm{H}$, at the borderline of stability of underlying medium-dense sand, but flatter than the angle of repose of the protective elements (mostly steeper than $1 \mathrm{~V}: 1 \mathrm{H}$ ) and consequently only resulting in a single, self-launched layer of protective elements.

Experience with a number of failures has led to three clear principles:

(i). Aprons do not work on unconsolidated, recently deposited soils, which form natural slopes of less than $1 \mathrm{~V}: 2 \mathrm{H}$.

(ii). Aprons do not work along narrow convex curvatures, such as at the end of a spur, because of the limited material available to cover the 'cone-shaped' underwater slope.

(iii). Uniform, hard elements do not work as aprons in sand-bed rivers. The large voids or gaps between individual elements result in substantial winnowing leading to the steepening of the 
slopes and eventually geotechnical failure. Observations show that geobags do not steepen the underwater slope significantly after repeated flow attacks (Figure 14).

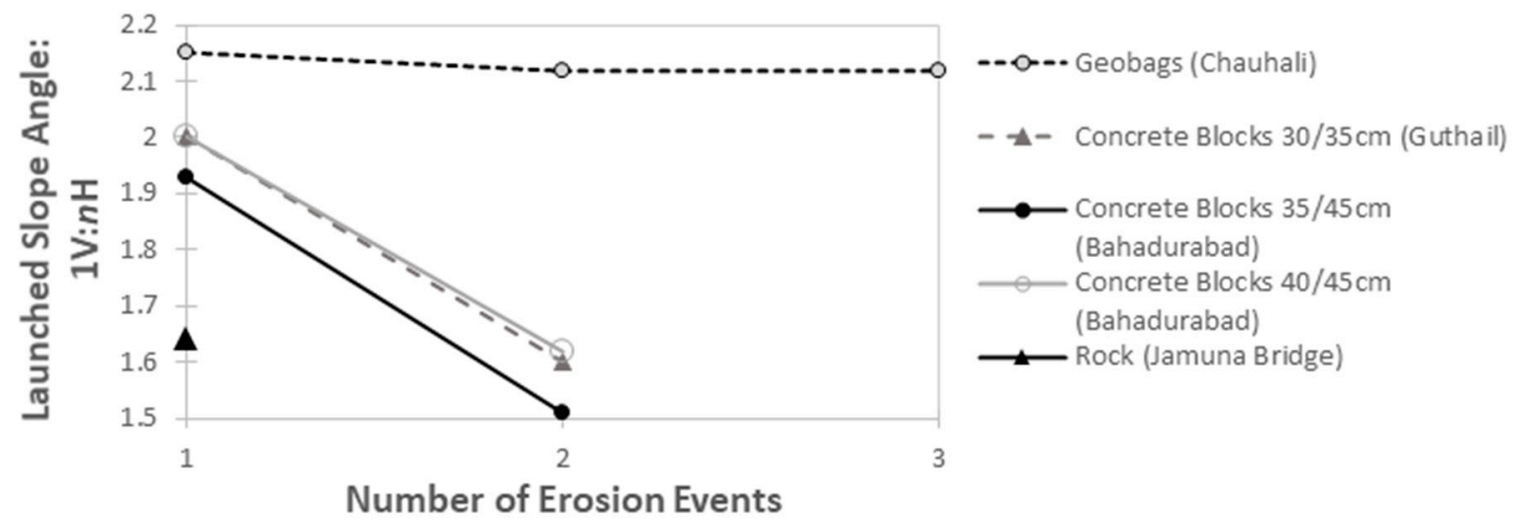

Figure 14. Slope angles of launched aprons after multiple attacks (data from Diggelmann [60] and recent investigations under FRERMIP [48]).

\subsection{Geotechnical Design Is Fundamental for Stable Riverbank Protection}

While the classical design in Bangladesh focused on flow velocities and the associated stability of protective elements, the geotechnical stability is also crucial for success of the structures. The understanding of geotechnical failure modes has improved over the last quarter century because of slope stability calculations, modification of designs to adjust to encounters of slope instability (for example slides during construction of the western guide bund of the Jamuna crossing and at Sirajganj), and collection of data for documentation of underwater failures. The upper $20 \mathrm{~m}$ of the lesser consolidated riverbanks are susceptible to liquefaction, while static flow slides induced by rapid scouring at the toe leads to retrogressive failure of the whole riverbank. What remains are uncertainties associated with the variability of the underlying subsoil. Unfortunately, for practical reasons, subsoil investigations cannot provide a continuous picture of all local weaknesses.

The present understanding indicates the application of several safety aspects when planning and designing riverbank protection from a geotechnical point of view. Firstly, the higher the requirements in the stability, the flatter the upper slopes must be. Secondly, the apron must be placed on consolidated strata in order to ensure that the launching angle of $1 \mathrm{~V}: 2 \mathrm{H}$ provides a reasonably stable slope. Thirdly, once launched, the apron must be upgraded to multiple layer coverage (adaptation works) to avoid winnowing failure over time. In summary, this means to disaggregate the underwater slope protection from the apron, ensuring that only the outer part of the apron launches during scouring, not the whole width.

Following the different soil classes, the above requirements result in four different design standards for geobag revetments (Figure 15). These different standards vary in various aspects such as the necessity of dredging, back cutting of the upper slope, and the required width of the apron. 


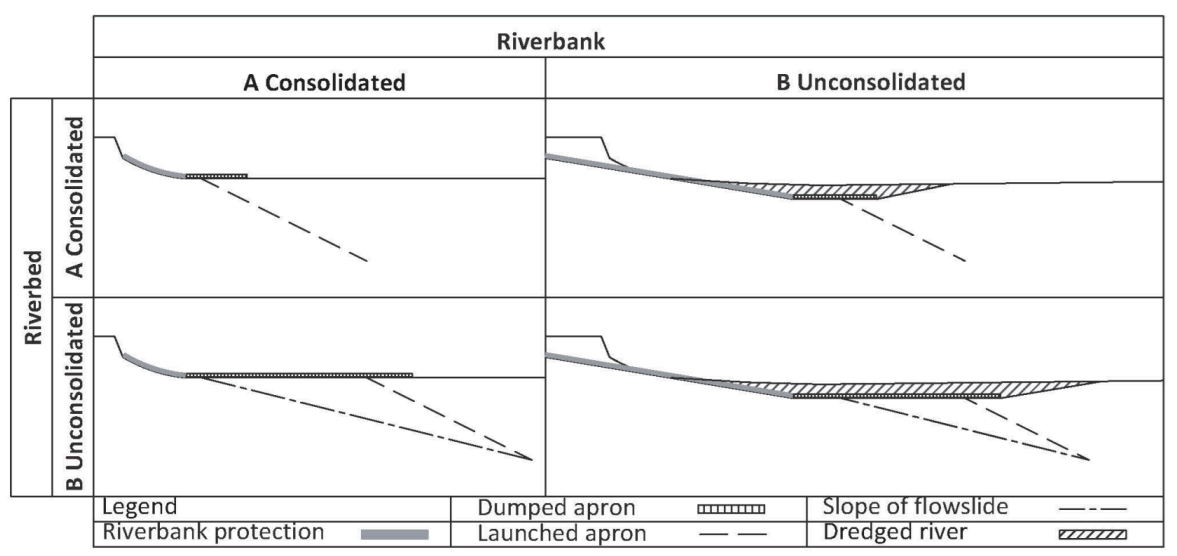

Figure 15. Comparison of riverbank protection designs for different geotechnical conditions.

\subsection{The Adaptive Approach for Sustainable Riverbank Protection}

The adaptive approach constitutes a risk-minimizing, flexible response to annually recurring, unpredictable, large-scale, and dominantly natural river processes. The adaptive approach has emerged since 2006 during the design development process of geobag revetments [13,49]. There are eight chief elements to the adaptive approach:

(i). Predicting the river behavior in order to facilitate the planning process.

(ii). Multi-year allocation of funds to river reaches. As the erosional attack can suddenly shift, especially after high floods, the riverbank protection activities need to follow the river behavior. This is best performed when working over longer river reaches (some 60 to $90 \mathrm{~km}$ in length) as there the annual requirements average out.

(iii). Design driven by geotechnical considerations. The construction methodology must be chosen in line with, and the selection of the apron width depend on the subsoil conditions (Figure 15). It is essential to reassess the location prior to construction as the bank lines can erode after planning and design.

(iv). Construction as per actual river requirement. The work is implemented based on surveys few days before dumping the protective materials. This ensures that the underwater slope and apron are reliably covered to meet the design intent.

(v). Preparation of as-built drawing to document the initial construction of the works.

(vi). Monitoring and evaluation. Regular monitoring starts immediately after construction and continues during the first two years when significant morphological changes are expected around the structure (for example Figure 12). This provides information on the status of the works and also signals when adaptation works are necessary.

(vii). Adaptation works are constructed (Figure 10). When an apron launches more than 5 to $8 \mathrm{~m}$ vertically (slope length 11 to $17 \mathrm{~m}$ ), adaptation works, or the upgrading of the single layer launched slope protection to multiple layers, are required. Further, an additional apron is constructed at the bottom of the launched slope in order to move the scour further away from the bank line. Adaptation works are ideally packaged for river reaches with five-year on-call contracts providing annually flexible allocations wherever required.

(viii).Maintenance for the long-term sustainability of the works. This includes the repair of local failures, such as slides due to undetected zones of weaker subsoil.

The adaptive approach has been implemented in many places in Bangladesh, at least in parts, even though often not termed as such. The clear advantage is that it de-connects new construction and maintenance, the latter of which is chronically underfinanced. Following an adaptive approach is a pragmatic way to build riverbank protection in sand-bed rivers to the design scour while minimizing the total investment cost. 


\section{Summary}

Building on more than 100 years of experience, Bangladesh has contributed substantially to the knowledge of river processes and river stabilization techniques in large, unstable, braided river systems. Documented knowledge on the large alluvial rivers of South Asia date back to the end of the 19 th century [17] and the first half of the 20th century [1,17,32]. The sequence of work on the large bridge crossings shows the evolution of knowledge regarding the long-term sustainability for high value infrastructure (Section 2). Beyond high value infrastructure, Bangladesh has contributed to the development of low-cost riverbank protection for much less valued agricultural lands. Major impetus was gained during the second half of the 1990s from new works built under the Flood Action Plan, specifically FAP 1 and FAP 21, and eventually led to the geobag revetments today (Section 3).

In addition to the development of riverbank protection technologies, knowledge of river processes has evolved. First contributions date back to the early 1990s (for example [61]). Erosion prediction methodologies have been developed by the Center for Environmental and Geographic Information Services (CEGIS) [45,62]. In parallel, Dr. Sarker, developed an explanation for why the Jamuna was widening after the 1950 Great Assam Earthquake [6,7].

All riverbank protections in Bangladesh must be adaptive. This requires systematic construction to deeper scour levels after initial launching of the aprons. Following the British railway engineers, the BWDB continued to use adaptive construction techniques. Examples include the town protections of Sirajganj and Chandpur, where the adaptation process has continued since the first construction in the 1960/1970. In 1938, Gales observed for bridge crossings over alluvial rivers without boundaries in general [17]: "It is, indeed, by building the bridges first and finding by experiences the difficulty there is in maintaining them ..." ". Related to Hardinge Bridge, he observed 20 years after construction: "Although the final form of the training-works for the Hardinge bridge has not yet been determined, much may be learned from a study of the testing experiences through which the works have recently passed."

An adaptive approach is strongly based on "learning by doing", which has not only enabled the development of geobag revetments, maximizing local resources, but also fostered data collection for study of the river behavior. The difficulty of the adaptive approach is the requirement of flexible contracts for river reaches.

The rivers of Bangladesh pose extreme challenges for engineers hoping to stabilize the riverbanks. Efforts of various projects and organizations have led to the development of low-cost geobag revetments, which has made it possible to create a stabilized river corridor. Today, efforts continue to improve on the design of riverbank protection and increase our understanding of these rivers in order to provide more stability to the population of Bangladesh in future.

Author Contributions: K.O. has contributed to this article by collecting and providing the article content, as well as composing the text. A.M.A.H. has contributed to this article by collecting the article content. A.T. has contributed to this article by assisting in composing the article text. All authors have read and agreed to the published version of the manuscript.

Funding: This work summarizes experience gained over the last more than 20 years for a number of mostly donor supported projects for different Clients in Bangladesh.

Acknowledgments: The authors would like to acknowledge the contributions of our colleagues, who were involved in the development of a broader understanding of the rivers in Bangladesh. We would like to recognize Maminul Haque Sarker for studying the causes of the river widening and developing an erosion prediction tool, Michael A. Stevens for introducing systematic ADCP measurements to understand flow processes when designing riverbank protection works, A.M.M. Safiullah and Herbert Fedinger for contributing to the understanding of the multitude of geotechnical failure possibilities, Michael Heibaum for contributing insight into the application and testing of geosynthetics, Mukhles-uz-zaman for systematic documentation of the historic works and preparing the main background for the Guideline for Riverbank Protection [12], Gerrit Klaassen for revitalizing the idea of a stable river corridor in 2009, the Project Directors Sharif Rafiqul Islam and M. Abdul Quddus for initiating JMREMP and FRERMIP, and last, but not least, Sharif Al Kamal and Kenichi Yokoyama for championing the development of a new type of riverbank protection in the BWDB through ADB financing in the early 2000s. Finally, the authors would like to thank their colleagues Saleh Adib Turash and Jesper Mathiesen for helping with the preparation of figures and tables.

Conflicts of Interest: The authors declare no conflict of interest. 


\section{References}

1. Gales, R.R. The Harding Bridge over the Lower Ganges at Sara; Institution of Civil Engineers: London, UK, 1917.

2. Schumm, S.; Winkley, B. The Variability of Large Alluvial Rivers; John Wiley and Sons: Hoboken, NJ, USA, 1994.

3. Maunsell|AECOM. Padma Multi-purpose Bridge Design Project, River Training Works, Final Design Report. In Prepared by Northwest Hydraulic Consultants for Bangladesh Bridge Authority, Main Report and 9 Annexes; AECOM: Los Angeles, CA, USA, 2011.

4. Rahman, M.; Dustegir, M.; Karim, R.; Haque, A.; Nichols, R.J.; Darby, S.E.; Nakagawa, H.; Hossain, M.; Dunn, F.E.; Akter, M. Recent sediment flux to the Ganges-Brahmaputra-Meghna delta system. Sci. Total Environ. 2018, 543, 1054-1064. [CrossRef]

5. Ahmed, T. Disaster-related Statistics, Bangladesh Experience. Available online: https://www.unescap.org/ sites/default/files/10_Bangladesh_Showcase-Disaster_Statistics.pdf (accessed on 26 October 2020).

6. Sarker, M.H. Morphological Response of the Brahmaputra-Padma-Lower Meghna River System to the Assam Earthquake of 1950. Ph.D. Thesis, University of Nottingham, Nottingham, UK, September 2008.

7. Sarker, M.H.; Thorne, C.R. Morphological Response of the Brahmaputra-Padma-Lower Meghna River System to the Assam Earthquake of 1950. In Braided Rivers; Smith, J., Best, C.B., Pettes, G.E., Eds.; Blackwell Publishing: Hoboken, NJ, USA, 2006.

8. CEGIS. Long-term Erosion Process of the Jamuna River. In Prepared for Jamuna-Meghna River Erosion Mitigation Project; CEGIS: Dhaka, Bangladesh, 2007.

9. Pilarczyk, K.W. Geosynthetics \& Geosystems in Hydraulic and Coastal Engineering; A.A. Balkema: Rotterdam, The Netherlands, 2000.

10. NHC-EMM. Flood and Riverbank Erosion Risk Management Investment Program; Bangladesh Water Development Board of the Asian Development Bank: Dhaka, Bangladesh, 2019.

11. DHV. Command Area Development Project (CADP), River Erosion Prevention and Morphology Study; Bangladesh Water Development Board, Ministry of Water Resources, Government of the People's Republic of Bangladesh: Dhaka, Bangladesh, 2000.

12. BRTS. Guidelines for River Bank Protection; Bureau of Research, Testing and Consultation, University of Engineering and Technology: Dhaka, Bangladesh, 2010.

13. Oberhagemann, K.; Hossain, M.M. Geotextile bag revetments for large rivers in Bangladesh. Geotext. Geomembr. 2011, 29. [CrossRef]

14. Oberhagemann, K.; Haque, A.M.A. Developments of Low Cost Riverbank Protection in Bangladesh. In Proceedings of the 8th International Conference on Scour and Erosion, Oxford, UK, 12-15 September 2016.

15. Thompson, A.; Oberhagemann, K.; She, Y.; Haque, A.M.A. The behavior of self-launching geotextile bag aprons- latest investigations from the Lower Brahmaputra in Bangladesh. In Proceedings of the 9th International Conference on Scour and Erosion, Taipei, Taiwan, 5-8 November 2018.

16. NCH-EMM. River Stabilization and Development: Jamuna-Padma and Dependent Areas; RPMC and CEGIS for the Bangladesh Water Development Board: Dhaka, Bangladesh, 2020.

17. Gales, R.R. The Principle of River-Training for Railway Bridges, and Their Application to the Case of the Hardinge Bridge over the Lower Ganges at Sara; Institution of Civil Engineers: London, UK, 1938.

18. Bell, J.R. The Continuous Bund and Apron Method of Protecting the Flanks of Bridges for Rivers in the Panjab (India); Techni. Paper No. 2B; Simla, India, 1890.

19. Tappin, R.G.R.; van Duivendijk, J.; Haque, M. The design and construction of Jamuna bridge, Bangladesh. Proc. Inst. Civ. Eng. 1998, 126. [CrossRef]

20. Neill, C.; Oberhagemann, K.; McLean, D.; Ferdous, Q.M. River Training Works for Padma Multipurpose Bridge, Bangladesh. In Proceedings of the IABSE JSCE Joint Conference on Advances in Bridge Engineering II, Dhaka, Bangladesh, 8-10 August 2010.

21. JICA. Interim Report on Feasibility Study for Jamuna River Bridge Construction Project; Japan International Cooperation Agency: Tokyo, Japan, 1974.

22. RPT, NEDECO, BCL. Jamuna Bridge Appraisal Study, Characteristics and Configuration-Phase I. Draft Final Report; Rendel Palmer \& Tritton: London, UK, 1987.

23. Nishimizu, M. Implementation Completion Report (IDA-25690) on a Credit in the Amount of SDR 143.6 Million (US\$200 Million Equivalent) to the People's Republic of Bangladesh for the Jamuna Bridge Project; World Bank: Washington, DC, USA, 2000. 
24. RPT, NEDECO, BCL. Padma Bridge Study, Phase I Prefeasibility Report; Rendel Palmer \& Tritton, NEDECO, and Bangladesh Consultants for Jamuna Multipurpose Bridge Authority: Dhaka, Bangladesh, 2000.

25. Nippon Koei. The Feasibility Study of Padma Bridge in the People's Republic of Bangladesh, Final Report; Nippon Koei Co. Ltd.: Tokyo, Japan, 2005.

26. Sarker, M.H.; Klaassen, G.J.; Noor, F.; Islam, M.S. Impact of the Bangabandhu Bridge on the Morphology of the Jamuna River, Bangladesh. In Proceedings of the 3rd International Conference on Water \& Flood Management (ICWFM-2011), Dhaka, Bangladesh, 8-11 January 2011.

27. RPT, NEDECO, BCL. Jamuna Bridge Project, Phase II Study, River Training Works Design Report; Rendel Palmer \& Tritton, NEDECO, and Bangladesh Consultants for Government of Bangladesh, United Nations Development Programme/World Bank: Dhaka, Bangladesh, 1990.

28. Oostinga, H.; Daemen, I. Construction of the River Training Works for the Jamuna Bridge Project in Bangladesh; International Association of Dredging Companies: Voorburg, The Netherlands, 1997; pp. 3-13.

29. Klaassen, G.J.; van Duivendijk, H.; Sarker, M.H. Performance review of Jamuna Bridge River Training Works 1997-2009. In Proceedings of the River Flow 2012 International Conference on Fluvial Hydraulics, San Jose, Costa Rica, 5-7 September 2012.

30. Slaa, B.T. River Training Works for a Bridge across the Brahmaputra river, Bangladesh. River Coastal and Shoreline Protection. In Erosion Control Using Riprap and Armourstone; Thorne, C.R., Abt, S.R., Barends, F.B.J., Maynard, S.T., Pilarczyk, K.W., Eds.; John Wiley \& Sons: Hoboken, NJ, USA, 1995.

31. Thompson, A.; Oberhagemann, K.; She, Y. Geobag stability for riverbank erosion protection structures: Physical model study. Geotext. Geomembr. 2019. [CrossRef]

32. Inglis, C.C. The Behavior and Control of River and Canals (With the Aide of Models); Central Water, Power, Irrigation and Navigation Research Station: Poona, India, 1949.

33. IECO. Master Plan; International Engineering Company for East Pakistan Water and Power Development Authority: Lahore, Pakistan, 1964.

34. Leedshill—Deleuw Engineers. Brahmaputra Flood Embankment Project, Phulchari to Siragjganj (I.D.A. Credit 39-PAK), Definite Project Report; East Pakistan Water and Power Development Authority: Lahore, Pakistan, 1965.

35. WARPO. Summary Report Based on Studies Carried out under the Flood Action Plan; Water Resources Planning Organization, Ministry of Water Resources, Government of the People's Republic of Bangladesh: Dhaka, Bangladesh, 1995.

36. Consulting Consortium FAP 21. River Training and Active Floodplain Management. Final Report Study Phase; Consulting Consortium FAP21/22 Rhein-Ruhr Ingenieur Gesellschaft: Essen, Germany, 1993.

37. Halcrow. River Training Studies of the Brahmaputra River, Master Plan Report; Sir William Halcrow \& Partners Ltd.: Swindon, UK, 1994.

38. ADB. Report and Recommendation of the President to the Board of Directors on a Proposed Loan to the People's Republic of Bangladesh for the Jamuna-Meghna River Erosion Mitigation Project; Asian Development Bank: Mandaluyong, Philippines, 2002.

39. Khan, H.; Oberhagemann, K.; Choubey, R.I.; Hawkswood, M.; Habib, A. Case studies of erosion protection pilots in Bangladesh: Embankments, bioengineering and using jute where it "mattress". In Proceedings of the Tenth International Conference on Scour and Erosion, Arlington, VA, USA, 17-20 October 2021.

40. Jamuna Test Works Consultants. Bank Protection and River Training (AFPM) Pilot Project FAP21/22 Final Project Evaluation Report; Consulting Consortium FAP21/22 for Government of the People's Republic of Bangladesh, Ministry of Water Resources, Water Resources Planning Organization: Dhaka, Bangladesh, 2001.

41. Fichtner and NHC. River Bank Improvement Program. Feasibility Study and Detailed Design Phase I Priority Reach; Government of the People's Republic of Bangladesh, Ministry of Water Resources, Bangladesh Water Development Board: Dhaka, Bangladesh, 2015.

42. Haskoning. Meghna River Bank Protection Short Term Study; Haskoning, Royal Dutch Consulting Engineers and Architects in Association with Delft Hydraulics and Bangladesh Engineering \& Technological Services for Bangladesh Water Development Board: Dhaka, Bangladesh, 1992.

43. Hotopp, D.; Oberhagemann, K.; Hossain, M. Scour development alongside Riverbank Protection in a braided River-selected cases from Bangladesh. In Proceedings of the 4th International Conference on Scour and Erosion, Tokyo, Japan, 5-7 November 2008.

44. Aitken, T. River Training in Bangladesh. Proc. Inst. Civ. Eng. 1992, 34, 313-321. 
45. CEGIS. Developing Empirical Method for Predicting Morphological Changes in the Padma River; Centre for Environmental and Geographic Information Services: Dhaka, Bangladesh, 2005.

46. CEGIS. Update, Improve and Extend the Erosion Forecasting and Warning Tools in the Three Main Rivers; Centre for Environmental and Geographic Information Services: Dhaka, Bangladesh, 2018.

47. Oberhagemann, K.; Al-Kamal, S. Geobag Protection in Bangladesh. In Proceedings of the 4th International Conference on Filters and Drainage in Geotechnical and Environmental Engineering, Geofilters, Stellenbosch, South Africa, 19-21 October 2004.

48. ADB. Report and Recommendation of the President to the Board of Directors. In Proposed Multi-tranche Financing Facility People's Republic of Bangladesh: Flood and Riverbank Erosion Risk Management Investment Program; Asian Development Bank: Mandaluyong, Philippines, 2014.

49. NHC. Jamuna-Meghna River Erosion Mitigation Project Part B, Special Report 23 Design Brief for Riverbank Protection Implemented under JMREMP (Update); Northwest Hydraulic Consultants in association with Beller Consult, Germany and Resources Planning and Management Consultants, Bangladesh for Bangladesh Water Development Board: Dhaka, Bangladesh, 2006.

50. Singh Nag, B. The Protection of Dibrugarh; Flood Control Department Assam: Shillong, India, 1956.

51. Maunsell|AECOM. Padma Multi-Purpose Bridge Design Project, River Training Works, Updated Scheme Design Report; Northwest Hydraulic Consultants for Bangladesh Bridge Authority: Dhaka, Bangladesh, 2010.

52. Heibaum, M.; Oberhagemann, K.; Faisal, M.A.; Haque, S. Geotextile Bags for sole permanent Bank Protection. In Proceedings of the 4th European Geosynthetics Conference, Edinburgh, Scotland, 7-10 September 2008.

53. Mosselman, E. Mathematical Modelling of Morphological Processes in Rivers with Erodible Cohesive Banks. Ph.D. Thesis, Delft University of Technology, Delft, The Netherlands, 1992.

54. Ali, M.E. Comprehensive Plan for Protection of Chandpur Town and Chandpur Irrigation Project; Bangladesh Water Development Board: Dhaka, Bangladesh, 1975.

55. Thomas, A.R.; Paton, A. Claude Cavendish Inglish, 3 March 1883-29 August 1974. Biogr. Mem. Fellows R. Soc. 1975, 21, 366-388.

56. CEGIS. Prediction of Riverbank Erosion along the Jamuna, the Ganges, and the Padma Rivers in 2018; Bangladesh Water Development Board: Dhaka, Bangladesh, 2018.

57. Van der Hoeven, M.A. Behaviour of a Falling Apron. Master's Thesis, Delft University of Technology, Delft, The Netherlands, January 2002.

58. Thiel, B. Behaviour of a Falling Apron Made From "Poorly Sorted" Material. Master's Thesis, Delft University of Technology, Delft, The Netherlands, April 2002.

59. Neill, C.R.; Mannerström, M.C.; Azad, A.K. Model Tests on Geobags for Erosion Protection. In Proceedings of the 4th International Conference on Scour and Erosion, Tokyo, Japan, 5-7 November 2008.

60. Diggelmann, P. Experiences with Falling Aprons in Bangladesh. Diploma Thesis, Swiss Federal Institute of Technology, Zürich, Switzerland, February 2007.

61. Klaassen, G.J.; Mosselman, E.; Brühl, H. On the Prediction of Planform Changes in Braided Sand-Bed Rivers; Delft Hydraulics: Delft, The Netherlands, 1993; pp. 134-146.

62. Environment and GIS Support Project for Water Sector Planning; Waterloopkundig Laboratorium (Delft, Netherlands); Water Resources Planning Organization (Bangladesh). Morphological Dynamics of the Brahmaputra-Jamuna River; The Project: Dhaka, Bangladesh, 1997.

Publisher's Note: MDPI stays neutral with regard to jurisdictional claims in published maps and institutional affiliations.

(C) 2020 by the authors. Licensee MDPI, Basel, Switzerland. This article is an open access article distributed under the terms and conditions of the Creative Commons Attribution (CC BY) license (http://creativecommons.org/licenses/by/4.0/). 